\title{
The E-NTPDase family of ectonucleotidases: Structure function relationships and pathophysiological significance
}

\author{
Simon C. Robson • Jean Sévigny • Herbert Zimmermann
}

Received: 21 December 2005 / Accepted: 23 January 2006 / Published online: 30 May 2006

(C) Springer Science + Business Media B.V. 2006

\begin{abstract}
Ectonucleotidases are ectoenzymes that hydrolyze extracellular nucleotides to the respective nucleosides. Within the past decade, ectonucleotidases belonging to several enzyme families have been discovered, cloned and characterized. In this article, we specifically address the cell surface-located members of the ecto-nucleoside triphosphate diphosphohydrolase (E-NTPDase/CD39) family (NTPDase1,2,3, and 8 ). The molecular identification of individual NTPDase subtypes, genetic engineering, mutational analyses, and the generation of subtype-specific antibodies have resulted in considerable insights into enzyme structure and function. These advances also allow definition of physiological and patho-physiological implications of NTPDases in a considerable variety of tissues. Biological actions of NTPDases are a consequence (at least in part) of the regulated phosphohydrolytic activity on extracellular nucleotides and consequent effects on P2-receptor signaling. It further appears that the spatial and temporal expression of NTPDases by various cell types within the vasculature, the nervous tissues and other tissues impacts on several
\end{abstract}

S. C. Robson

Department of Medicine, Beth Israel Deaconess Medical Center, Harvard Medical School,

Boston, Massachusetts, USA

J. Sévigny

Centre de Recherche en Rhumatologie et Immunologie,

Université Laval, Québec, Québec, Canada

H. Zimmermann ( $\square)$

Institut fuer Zellbiologie und Neurowissenschaft,

Biozentrum der J.W. Goethe-Universitaet,

Marie-Curie-Str. 9, D-60439, Frankfurt am Main, Germany

e-mail: h.zimmermann@cns.uni-frankurt.de patho-physiological processes. Examples include acute effects on cellular metabolism, adhesion, activation and migration with other protracted impacts upon developmental responses, inclusive of cellular proliferation, differentiation and apoptosis, as seen with atherosclerosis, degenerative neurological diseases and immune rejection of transplanted organs and cells. Future clinical applications are expected to involve the development of new therapeutic strategies for transplantation and various inflammatory cardiovascular, gastrointestinal and neurological diseases.

Keywords apyrase - brain - CD39 - ecto-ATPase immunology $\cdot$ ischemia $\cdot$ kidney $\cdot$ liver $\cdot$ nervous tissue . NTPDase $\cdot$ platelet $\cdot$ vasculature

\begin{tabular}{|c|c|}
\hline \multicolumn{2}{|c|}{ Abbreviations } \\
\hline $\mathrm{ACR}$ & apyrase conserved regions \\
\hline ADA & adenosine deaminase \\
\hline ATPDase & ATP diphosphohydrolase \\
\hline bFGF & basic fibroblast growth factor \\
\hline CCK-8 & cholecystokinin octapeptide- 8 \\
\hline EC & endothelial cell \\
\hline E-NTPDase & $\begin{array}{l}\text { ecto-nucleoside triphosphate } \\
\text { diphosphohydrolase }\end{array}$ \\
\hline ERK & extracellular regulated kinase \\
\hline FAK & focal adhesion kinase \\
\hline MAP & mitogen-activated protein \\
\hline MAPK & MAP kinase \\
\hline NO & nitric oxide \\
\hline NPP & $\begin{array}{l}\text { nucleotide pyrophosphatase/ } \\
\text { phosphodiesterase }\end{array}$ \\
\hline NTPDase & $\begin{array}{l}\text { nucleoside triphosphate } \\
\text { diphosphohydrolase }\end{array}$ \\
\hline PDGF & platelet derived growth factor \\
\hline
\end{tabular}




$\begin{array}{ll}\text { PI3K } & \text { phosphatidylinositol 3-kinase } \\ \text { RanBPM } & \text { ran binding protein } \\ \text { TCDD } & \text { tetrachlorodibenzo- } p \text { dioxin }\end{array}$

\section{Introduction}

Extracellular nucleotides modulate a multiplicity of tissue functions including development, blood flow, secretion, inflammation and immune reactions. Indeed, signaling via extracellular nucleotides has been recognized for over a decade as one of the most ubiquitous intercellular signaling mechanisms [1,2]. Essentially every cell in a mammalian organism leaks or releases these mediators, and carries receptors for nucleotides of which seven ionotropic (P2X) and at least eight metabotropic (P2Y) receptor subtypes have been identified and characterized to date. Whereas $\mathrm{P} 2 \mathrm{X}$ receptors respond to ATP, $\mathrm{P} 2 \mathrm{Y}$ receptors can be activated by ATP, ADP, UTP, UDP, ITP, and nucleotide sugars, albeit agonist specificity varies between subtypes and the multiple animal species [3]. Depending on the $\mathrm{P} 2$ receptor subtype and signaling pathways involved, these receptors trigger and mediate short-term (acute) processes that affect cellular metabolism, adhesion, activation or migration. In addition, purinergic signaling also has profound impacts upon other more protracted responses, including cell proliferation, differentiation and apoptosis, such as seen in atherosclerosis, degenerative neurological diseases and in several inflammatory conditions $[2,4,5]$.

The effects of extracellular nucleotides appear to overlap, at least in part, with those of vascular growth factors, cytokines (inflammatory), adhesion molecules and nitric oxide (NO). Nucleotide-mediated activation may be also synergistic with polypeptide growth factors (PDGF, bFGF) and insulin, the signaling being mediated via phospholipase $\mathrm{C}$ and $\mathrm{D}$, diacylglycerol, protein kinase C, ERKs, phosphatidylinositol 3-kinases (PI3K), MAP kinases (MAPK) and Rho [6-8]. The situation concerning extracellular nucleotide-signaling can be suitably contrasted with the unique specificity of peptide hormones or vasoactive factors for often single, defined receptors [9, 10]. Within purinergic/ pyrimidinergic signaling events specificity is dictated by three essential modulatory components: 1) The derivation or source of the extracellular nucleotides [1, 11, 12]; 2) the expression of specific receptors for these molecular transmitters (and for the nucleotide and nucleoside derivatives) [13-16] (See also Molecular Recognition Section of National Institutes of Health, http://mgddk1.niddk.nih.gov/ also http://www.ensembl. org/index.html and http://www.geocities.com/bioinformaticsweb/speciesspecificdatabases.htm), and, 3) select ectonucleotidases that dictate the cellular responses by the stepwise degradation of extracellular nucleotides to nucleosides [17-20].

\section{Ensembles of ectonucleotidases, associated receptors and signaling molecules}

Within the past decade, ectonucleotidases belonging to several enzyme families have been discovered, cloned and functionally characterized by pharmacological means. Specifically, we refer here to members of the ecto-nucleoside triphosphate diphosphohydrolase (ENTPDase) family (EC 3.6.1.5) as ectoenzymes that hydrolyze extracellular nucleoside tri- and diphosphates and have a defined pharmacological profile. Most notably, in many tissues and cells, NTPDases comprise dominant parts of a complex cell surfacelocated nucleotide hydrolyzing and interconverting machinery. This ensemble includes the ecto-nucleotide pyrophosphatase phosphodiesterases (E-NPPs), NADglycohydrolases, CD38/NADase, alkaline phosphatases, dinucleoside polyphosphate hydrolases, adenylate kinase, nucleoside diphosphate kinase, and potentially ecto-F1-Fo ATP synthases [21-25] that may interact in various tissues and cellular systems.

The ectonucleotidase chain or cascade, as initiated by NTPDases can be terminated by ecto- $5^{\prime}$-nucleotidase (CD73; EC 3.1.3.5) with hydrolysis of nucleoside monophosphates [26]. Together, ecto-5'-nucleotidase and adenosine deaminase (ADA; EC 3.5.4.4), another ectoenzyme that is involved in purine salvage pathways and converts adenosine to inosine, closely regulate local and pericellular extracellular and plasma concentrations of adenosine [10, 27].

Several of these ectonucleotidase families and additional functions of NTPDases [28-30] are addressed elsewhere in this issue in detail. This review focuses on the surface-located mammalian members of the E-NTPDase protein family. It starts with a brief introduction of molecular structure and functional properties, followed by an analysis of the physiological and pathophysiological roles at various sites with an emphasis on vasculature and neural tissues.

\section{Molecular identities unraveled}

The literature on the molecular and functional characterization of the E-NTPDase family has been intensively reviewed [18-22, 31-36] and will not be 
repeated here in detail. Our intent is to summarize principal properties of the enzymes that will be of use for the reader new to this field.

Eight different ENTPD genes (Table 1 and Fig. 1) encode members of the NTPDase protein family. Four of the NTPDases are typical cell surface-located enzymes with an extracellularly facing catalytic site (NTPDase1, 2, 3, 8). NTPDases 5 and 6 exhibit intracellular localization and undergo secretion after heterologous expression. NTPDases 4 and 7 are entirely intracellularly located, facing the lumen of cytoplasmic organelles (Fig. 1). The molecular identification of individual NTPDase subtypes, genetic engineering, mutational analyses, and the generation of subtypespecific antibodies have not only led to considerable insight into enzyme structure and function. These advances have also defined physiological and pathophysiological functions of NTPDases in a considerable variety of tissues.

The presence of ATP and/or ADP hydrolyzing activity at the surface of many cell types had been recognized for several decades [17, 37-40]. However, the molecular identity of the first member of the ENTPDase family (NTPDase1) was not unraveled and determined until the mid-1990s. The prototypic member of the enzyme family had first been cloned and sequenced as a lymphocyte cell activation (CD39) antigen of undetermined function [41]. Final success came from three independent approaches. Handa and Guidotti [42] purified and cloned a soluble ATP diphosphohydrolase (apyrase) from potato tubers and noted that this protein was related not only to similar enzymes of some protozoans, plants and yeast but also to human CD39. They also recognized conserved sequence domains and the relation to members of the actin-hsp70-hexokinase superfamily. This was then followed by the functional expression of human CD39 and the demonstration that this protein was in fact an ecto-apyrase [43]. In parallel, ectonucleotidases (termed ATP diphosphohydrolases) from porcine pancreas and bovine aorta were purified. The partial amino acid sequences for both ATP diphosphohydrolases revealed identity with the cloned cDNA sequence of CD39 [44]. The cDNA was isolated from human endothelial cells and functional, thromboregulatory studies confirmed that the dominant vascular ectonucleotidase (ATP diphosphohydrolase) activity was identical to the previously described and cloned human CD39 [44]. Several internal peptide sequences obtained from the purified human placental ATP diphosphohydrolase [45] revealed that in retrospect this protein was also identical to CD39.

It was originally thought that there existed a single ectonucleotidase of the NTPDase type with potential post-translational modifications [46]. However, a close molecular relative was soon cloned that re-

Table 1 Nomenclature of mammalian members of the E-NTPDase family and chromosomal localization

\begin{tabular}{|c|c|c|c|c|}
\hline Protein name & Additional names & $\begin{array}{l}\text { Gene name } \\
\text { human, mouse }\end{array}$ & $\begin{array}{l}\text { Chromosome location } \\
\text { human, mouse }\end{array}$ & $\begin{array}{l}\text { Accession number } \\
\text { human, mouse }\end{array}$ \\
\hline NTPDase1 & $\begin{array}{l}\text { CD39, ATPDase, } \\
\text { ecto-apyrase }[43,44]\end{array}$ & ENTPD1, Entpd1 & $10 \mathrm{q} 24,19 \mathrm{C} 3$ & U87967, NM_009848 \\
\hline NTPDase2 & $\begin{array}{l}\text { CD39L1, ecto-ATPase } \\
{[49,109,252]}\end{array}$ & ENTPD2, Entpd2 & $9 \mathrm{q} 34,2 \mathrm{~A} 3$ & AF144748, AY376711 \\
\hline NTPDase3 & $\begin{array}{l}\text { CD39L3, HB6 } \\
{[50,177]}\end{array}$ & ENTPD3, Entpd3 & $3 \mathrm{p} 21.3,9 \mathrm{~F} 4$ & AF034840, AY376710 \\
\hline NTPDase4 & $\begin{array}{l}\text { UDPase, LALP70 } \\
{[253,254]}\end{array}$ & ENTPD4, Entpd4 & 8p21, 14D1 & AF016032, NM_026174 \\
\hline NTPDase 5 & $\begin{array}{l}\text { CD39L4, } \\
\text { ER-UDPase, PCPH } \\
{[137,255,256]}\end{array}$ & ENTPD5, Entpd5 & $14 \mathrm{q} 24,12 \mathrm{E}(12 \mathrm{D} 1)^{\mathrm{a}}$ & AF039918, AJ238636 \\
\hline NTPDase6 & CD39L2 [257-259] & ENTPD6, Entpd6 & 20p11.2, $2 \mathrm{G} 3$ & AY327581, NM_172117 \\
\hline NTPDase7 & LALP1 [260] & ENTPD7, Entpd7 & 10q24, 19D1 (19C3) ${ }^{\mathrm{a}}$ & AF269255, AF288221 \\
\hline NTPDase8 & $\begin{array}{l}\text { liver canalicular } \\
\text { ecto-ATPase, } \\
\text { hATPDase }[52,174]\end{array}$ & ENTPD8, Entpd8 & $9 \mathrm{q} 34,2 \mathrm{~A} 3$ & AY430414, AY364442 \\
\hline
\end{tabular}

Information is provided for the human genome from GenBank (http://www.ncbi.nlm.nih.gov) and mouse genome informatics (MGI) for the mouse genome (http://www.informatics.jax.org/). Since the mouse genome represents a composite assembly that continues to undergo updates and changes from build to build, the computed map locations may be corrected in the future.

${ }^{a}$ For mouse Entpd5 and Entpd7, the BLAST analysis displayed in Map Viewer indicates a different map location (in brackets) when compared with the mapping data reported on MGI records using cytoband information based on experimental evidence. 


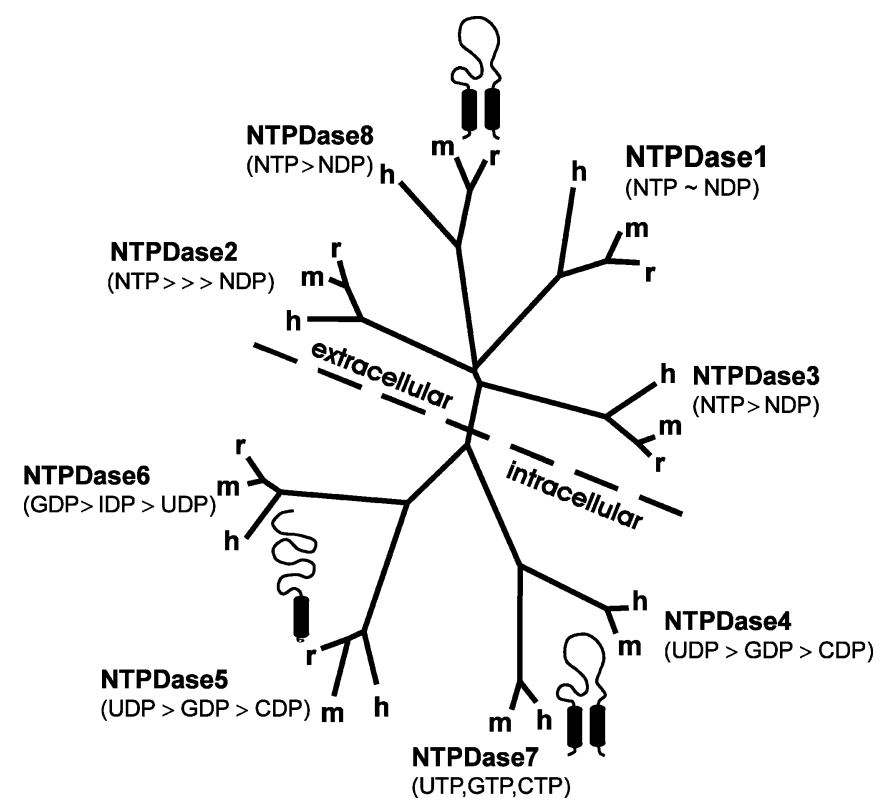

Fig. 1 Hypothetical phylogenetic tree derived for 22 selected members of the E-NTPDase family (NTPDase1 to NTPDase8) from rat $(r)$, human $(h)$ and mouse $(m)$, following alignment of amino acid sequences. The length of the lines indicates the differences between amino acid sequences. The graph depicts a clear separation between surface-located (top) and intracellular (bottom) NTPDases. In addition, the major substrate preferences of individual subtypes and the predicted membrane topography for each group of enzymes is given (one or two transmembrane domains, indicated by barrels). Modified from [59].

vealed functional properties of an ecto-ATPase (now NTPDase2) rather than of an ecto-ATP diphosphohydrolase [47, 48]. Further human genomic analysis of expressed sequence tags (ESTs) allowed the identification of additional members of the gene family [4951]. These genes were originally named CD39L(ike) 1 to $C D 39 L 4$. Then followed the identification, cloning and functional expression of all members of the ENTPDase family, the last to date being NTPDase8 [52].

Potential splice variants have been isolated for the surface-located NTPDase1 and NTPDase2 [for references see 34, 53]. It should be further noted that heterologous expression of potential splice variants does not necessarily result in the formation of a functional protein [54].

The initially proposed nomenclature [50] has been somewhat confusing as it did not meet with generally accepted norms for human cell differentiation molecules [55]. While CD39 (now NTPDase1) indeed belongs to the cluster of differentiation antigens, CD39L1 (NTPDase2), CD39L3 (NTPDase3), CD39L4 (NTPDase5) and CD39L2 (NTPDase6) do not. Scientists at the Second International Workshop on Ecto-ATPases proposed that all E-NTPDase family members be termed as NTPDase proteins and classified in order of discovery and characterization [34, 56]. The CD39 nomenclature should fall away for all but the prototypic member NTPDase1 that already has a long history of use in the Immunology and Oncology fields. Further revisions are however inevitable.

\section{Catalytic properties}

The individual NTPDase subtypes differ in cellular location and functional properties. The four cell surface-located forms (NTPDase1,2,3,8) can be differentiated according to substrate preference, divalent cation usage and product formation. All surfacelocated NTPDases require $\mathrm{Ca}^{2+}$ or $\mathrm{Mg}^{2+}$ ions in the millimolar range for maximal activity and are inactive in their absence $[34,57]$. They all hydrolyze nucleoside triphosphates including the physiologically active ATP and UTP. Notably, the hydrolysis rates for nucleoside diphosphates vary considerably between subtypes (Figs. 1 and 2). Whereas NTPDase1 hydrolyzes ATP and ADP about equally well, NTPDase 3 and NTPDase8 reveal a preference for ATP over ADP as substrate. NTPDase2 stands out for its high preference for nucleoside triphosphates and therefore has previously also been classified as an ecto-ATPase [34, 57]. In contrast to NTPDase1 and NTPDase2, murine NTPDase 3 and NTPDase8 are preferentially activated by $\mathrm{Ca}^{2+}$ over $\mathrm{Mg}^{2+}[52,58,59]$. Presumably, differences in sequence but also in secondary, tertiary and quaternary structure account for differences between subtypes in the catalytic properties [60,61]. 

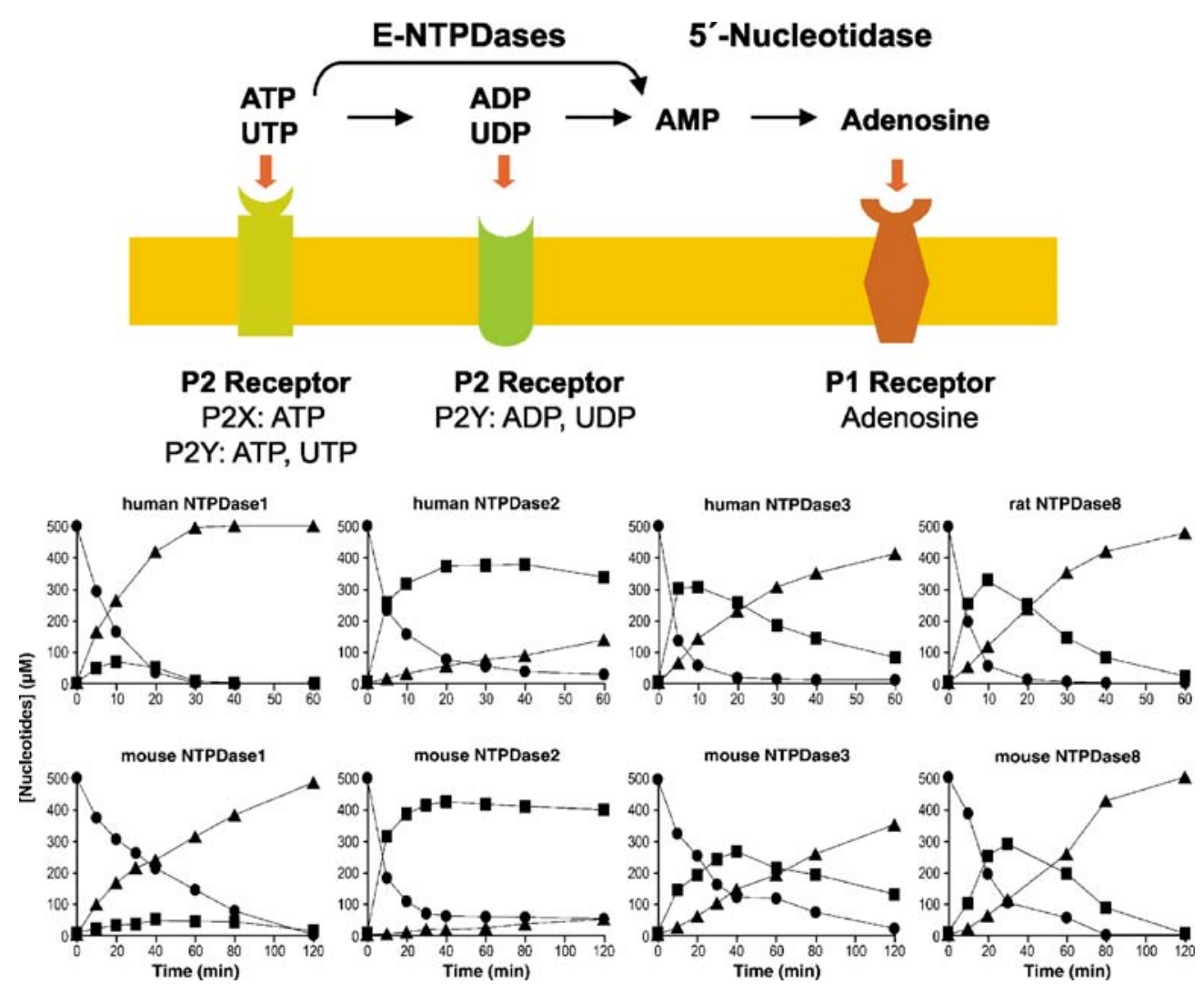

Fig. 2 Cell surface-located catabolism of extracellular nucleotides and potential activation of receptors for nucleotides (P2 receptors) and adenosine (P1 receptors). The figure depicts the principal catalytic properties of members of the E-NTPDase family and of ecto5 '-nucleotidase. NTPDases sequentially convert ATP to ADP + Pi and ADP to AMP + Pi. NTPDase1 is distinct among these enzymes as it dephosphorylates ATP directly to AMP without the release of significant amounts of ADP. Hydrolysis of the nucleoside monophosphate to the nucleoside is catalyzed by ecto-5'-nucleotidase. NTPDases, NPPs and alkaline phosphatase sometimes co-exist and it seems likely that they can act in concert to metabolize extracellular nucleotides. ATP can activate both P2X receptors and subtypes P2Y receptors whereas UTP activates subtypes of P2Y receptors only. After degradation, ADP or UDP may activate additional subtypes of $\mathrm{P} 2 \mathrm{Y}$ receptors. The adenosine formed can potentially act on four different types of P1 receptors and is either deaminated to inosine or directly recycled via nucleoside transporters. Bottom: Profiles of nucleotide hydrolysis and substrate formation by plasma membrane-located NTPDases. The figure compares catalytic properties of human and murine NTPDase1,2,3 and 8 , following expression in COS-7 cells. The principal catalytic properties of the respective human and murine enzymes are similar. ATP (•), ADP $(\boldsymbol{\square})$, AMP (山). Modified from [57].

Membrane-bound NTPDase1 hydrolyzes ATP almost directly to AMP with the transient production of minor amounts of free ADP (Fig. 2). This functional property largely circumvents activation of P2Y-receptors for nucleoside diphosphates. Interestingly, significant amounts of UDP are accumulated when UTP is hydrolyzed by NTPDase1 [57]. In contrast, ADP is released upon ATP hydrolysis by NTPDase2, then accumulates and is slowly dephosphorylated to AMP. On the one hand, this results in the removal of agonists for nucleoside triphosphate-sensitive P2Y-receptors (Fig. 2). On the other hand, it generates agonists for nucleoside diphosphate-sensitive receptors such as platelet $\mathrm{P}_{2} \mathrm{Y}_{1}$ and $\mathrm{P} 2 \mathrm{Y}_{12}$ receptors [62]. The actions of NTPDase 3 and NTPDase 8 result in intermediate patterns of product formation, leading to a transient accumulation of diphosphonucleosides with the simultaneous presence of triphosphonucleosides.

\section{Principal structural features}

The hallmarks of all NTPDases are the five highly conserved sequence domains known as 'apyrase conserved regions', abbreviated and termed ACR1 to ACR5 [42, 63, 64] that are involved in the catalytic cycle. This notion is supported by a considerable variety of deletion and mutation experiments [for reviews see 30, 34, 64-68].

NTPDases share two common sequence motifs with members of the actin/HSP70/sugar kinase superfamily, the actin-HSP 70-hexokinase $\beta$ - and $\gamma$-phosphate binding motif $[(\mathrm{I} / \mathrm{L} / \mathrm{V}) \mathrm{X}(\mathrm{I} / \mathrm{L} / \mathrm{V} / \mathrm{C}) \mathrm{DXG}(\mathrm{T} / \mathrm{S} / \mathrm{G})(\mathrm{T} / \mathrm{S} /$ $\mathrm{G}) \mathrm{XX}(\mathrm{R} / \mathrm{K} / \mathrm{C})][42,47,69,70]$, with the $\mathrm{DXG}$ sequence strictly conserved. These motifs are identified in ACR1 and ACR4. Furthermore, there are striking similarities in secondary structure with members of the actin/HSP70/sugar kinase superfamily [30, 
59, 71]. These proteins are soluble, have ATP phosphotransferase or hydrolase activity, depend on divalent metal ion and tend to form oligomeric structures. In spite of negligible global sequence identity they share the principal structure of two major domains (I and II, possibly resulting from gene duplication) of similar folds on either side of a large cleft. They reveal similar conserved secondary structure topology $(\beta 1 \beta 2 \beta 3 \alpha 1 \beta 4 \alpha 2 \beta 5 \alpha 3)$ repeated in each domain and fold into a pocket for substrate binding at the bottom [59]. Presumably, NTPDases share not only secondary structure but also major elements of tertiary structure with members of the actin/HSP70/sugar kinase superfamily (Fig. 3). Homology modeling of the NTPDase3 sequence reveals high degrees of structural fold similarity with a bacterial exopolyphosphatase (PDB 1T6C) that further refine structural predictions for members of the E-NTPDase family [30, 72].

NTPDases readily form homo-oligomeric assemblies. NTPDase1 to NTPDase3 were found as dimers to tetramers $[29,64,73-78]$. In contrast to the P2X receptors that share a similar membrane topography, hetero-oligomeric complexes between NTPDases have not been reported, to date. Oligomeric forms

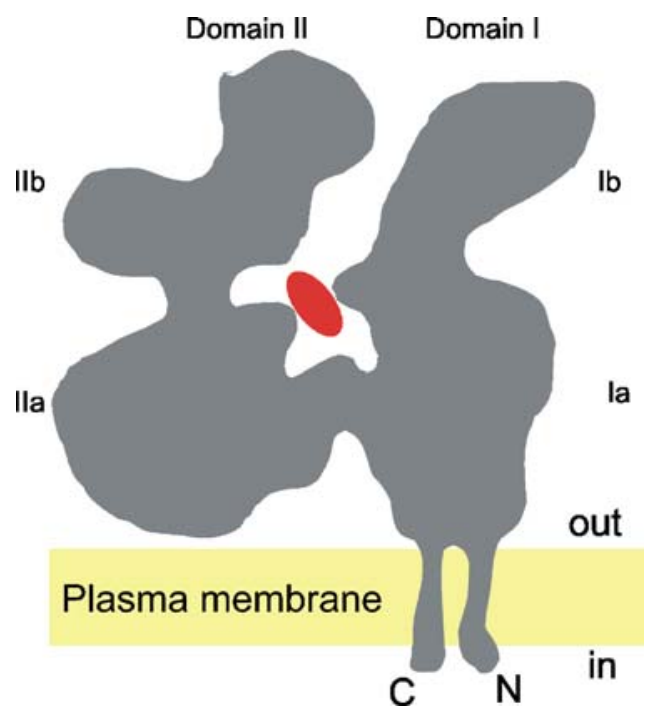

Fig. 3 Hypothetical membrane topology of a surface-located NTPDase with two transmembrane domains. A comparison of the conserved secondary structure reveals duplicate conservation of two major domains related to subdomains Ia and IIa of actin, and other members of the actin/HSP70/sugar kinase superfamily [59]. In contrast to the other members of the superfamily, surface-located NTPDases are anchored to the plasma membrane by terminal hydrophobic domains. The figure takes into account the close distance of the $\mathrm{N}$ - and $\mathrm{C}$-terminus of actin at domain I and the binding of ATP (red) in the cleft between domains I and II [80]. These two domains are expected to undergo conformational changes involving movement relative to each other. reveal increased catalytic activity $[73,75,76]$ and the state of oligomerization can affect catalytic properties $[77,78]$.

NTPDase1,2,3, and 8 are firmly anchored to the membrane via two transmembrane domains that in the instance of NTPDase1 are important for maintaining catalytic activity and substrate specificity [29, $64,79]$. The two transmembrane domains interact both within and between monomers. They may also undergo coordinated motions during the process of nucleotide binding and hydrolysis [29, 61]. This could in turn induce conformational changes [80] involving movement of the two major domains (I and II) relative to each other (Fig. 3). Alterations in quarternary structure and subunit interactions may thus affect the impact or interaction of ACRs involved in substrate binding and hydrolysis. Whether posttranslational modifications such as protein phosphorylation contribute to this dynamic behavior remains to be investigated.

\section{Functional modifications}

Biologically active NTPDase 1 is subject to differential forms of surface modification under conditions of oxidative stress that inhibit enzymatic activity, as influenced by unsaturated fatty acids [81, 82]. It also undergoes limited proteolysis that increases enzyme activity and differential glycosylation reactions that appear to be required for membrane expression [64]. Since the surface-located ATP-hydrolyzing members of the NTPDase family pass through the endoplasmic reticulum and Golgi apparatus, the associated catalytic activity might abrogate ATP-dependent luminal functional processes. NTPDase 1 becomes catalytically active on reaching the cell surface and glycosylation reactions appear crucial in this respect [83].

The N-terminal intracytoplasmic domain of NTPDase1 is palmitoylated. Truncated forms of NTPDase1 lacking the $\mathrm{N}$-terminal intracytoplasmic region and the associated $\mathrm{Cys}_{13}$ residue, are not subject to palmitoylation. This post-translational modification appears to be constitutive and to contribute to the integral membrane association of this ectonucleotidase in lipid rafts [84-86]. This raises the possibility that NTPDase1 may be recycled to and from cell membranes via sequential actions of putative palmitoyltransferases and palmitoyl-protein thioesterases [87], in order to fine tune and modulate purinergic signaling responses. In contrast to NTPDase1 and NTPDase3, NTPDase2 does not have the required intra-cytoplasmic Cys to undergo this post-translational modification. The potential multimerization of NTPDase1 [35] may be 
facilitated by acylation with intermolecular interactions within the cholesterol and sphingolipid-rich microdomains of the plasma membrane [88]. Experiments using endothelial cells from caveolin-1 deficient mice suggest that caveolae are not essential for the enzymatic activity or for the targeting to the plasma membrane of NTPDase1. However, cholesterol depletion results in a strong inhibition of the enzyme [86]. The targeting of palmitoylated NTPDase1 to lipid rafts could influence defined G-protein coupled receptors within this plasmalemmal microenvironment and thus regulate cellular signal transduction pathways. Furthermore, the caveolar co-localization of ecto-5'-nucleotidase, $\mathrm{P} 2$ receptors, and NTPDase 1 could serve to modulate signaling via both ATP and adenosine at the cell surface and possibly also within endosomal compartments [20].

\section{Transcriptional regulation of expression}

Members of the E-NTPDase family are constitutively expressed in many tissues. To date, there is only scattered evidence on promoters and the factors controlling NTPDase expression [22]. The transcription of NTPDase1/CD39 is constitutive in venous, arterial and certain non-fenestrated microvascular endothelium and certain immune cells e.g., B cells, dendritic cells and defined T-cell subsets [20, 89]. The modulated expression of NTPDase1 has been closely associated with inflammatory cytokines, oxidative stress and hypoxia in vitro and in vivo [19, 90].

Expression of NTPDase1 is increased in differentiating melanomas followed by a gradual decrease with tumor progression [91] and enhanced NTPDase1 activity of stimulated endothelial and mesangial cells is downregulated by glucocorticosteroids [92]. Activity of 'ecto-ATP diphosphohydrolase' in human endothelial cells in-vitro is increased by aspirin [93] and glomerular 'ecto-ATP diphosphohydrolase' immunoreactivity might well be modulated by estradiol [94].

Transcription of NTPDase2 in mouse hepatoma cells is inducible by $2,3,7,8$-tetrachlorodibenzo- $p$-dioxin (TCDD) [95]. These cells contain both constitutive and TCDD-inducible NTPDase 2 activity. The NTPDase 2 core promotor reveals constitutive activity that is independent of TCDD [96]. TCDD does not increase expression of NTPDase1, NTPDase3 or other ectonucleotidases and apparently fails to induce NTPDase2 in a variety of other cell lines derived from varying species [97]. In rat Sertoli cells, NTPDase2 is upregulated by follicle-stimulating hormone and cAMP [98] and it is selectively downregulated in biliary cirrhosis
[99]. Human epidermoid carcinoma cells increase the cascade for extracellular nucleotide hydrolysis when periodically treated with extracellular ATP, suggesting that the substrate itself may affect the expression of its own hydrolysis chain [100].

\section{Inhibitors}

A considerable number of compounds alter and inhibit extracellular nucleotide hydrolysis by NTPDases. These include non-hydrolysable nucleotide analogues and inhibitors of P2 receptors. Ideally, NTPDase inhibitors should not be $\mathrm{P} 2$ receptor agonists or antagonists and not be subject to dephosphorylation by the ectoenzyme [22, 101, 102]. The only commercially available compound reported to effectively inhibit hydrolysis of ATP in a variety of tissues without significantly acting on purinoceptors is the structural analogue of ATP, ARL 67156 (FPL 67156) (6- $N$, $N$-diethyl-D- $\beta, \gamma$-dibromomethylene ATP) [103105]. Other potential inhibitors include 8-thiobutyladenosine 5'-triphosphate (8-BuS-ATP) [106] and 1-naphthol-3, 6-disulfonic acid (BG0136) [101]. Periodate-oxidized ATP inhibits ecto-ATPase activity in 1312N1 human astrocytoma cells [107] and Gadolinium ions have been found to effectively inhibit the ecto-nucleoside triphosphate diphosphohydrolase from Torpedo electric organ as well as potato apyrase [108].

It is noteworthy that the potency of inhibitors can vary considerably between individual members of the E-NTPDase family [109-111]. This necessitates a functional evaluation of each inhibitor for the enzyme investigated in a given tissue or cell type. The failure to develop specific inhibitors remains a major impediment to ongoing discoveries.

\section{Principal functional contexts}

Cell surface-located NTPDases are considered to be of major importance for controlling the availability of extracellular nucleotide agonists at $\mathrm{P} 2$ receptors. They also contribute to recycling of nucleosides derived from extracellular nucleoside phosphates and metabolic salvage pathways. The number of studies that define a functional impact of individual NTPDases in purinergic signaling in situ is limited and has been dependent to date on global genetic modifications of mice and swine to delete or upregulate the NTPDase or P2 gene of interest [20]. Subtype-specific inhibitors, siRNA approaches, and animals in which the encoding 
gene can be inactivated or selectively induced in specific tissues will be of major importance.

There is increasing experimental evidence that ectonucleotidases compete with P2 receptors for a limited pool of endogenously released nucleotide [112, 113] and - by hydrolyzing released nucleotide terminate or modulate the function of $\mathrm{P} 2$ receptors [114-116]. Portal fibroblasts regulate P2Y receptormediated bile duct epithelial proliferation via expression of NTPDase2 [117] (see liver section, below). NTPDases functionally interact with P2Y-receptors [112] and may also co-localize with these G-proteincoupled receptors (GPCR) in lipid rafts and possibly caveolae [118-121]. The modulatory effects of NTPDases are complex as the enzymes differentially regulate agonist availability in a process that is dependent upon $\mathrm{P} 2$ receptor subtype by either degrading ATP/UTP or by generating ADP/UDP (Fig. 2).

Recent experiments suggest that plasma membranebound NTPDases may have functions distinct from their catalytic properties alone. In a yeast two-hybrid system using techniques developed by Zhong for yeast apyrases [122], the N-terminus of human NTPDase1 (used as bait protein) has been shown to interact with truncated Ran Binding Protein M (RanBPM, otherwise known as RanBP9, NM_005493) in the human library screened [122a]. RanBPM contains conserved SPRY (repeats in splA and RyR) domains that appear to be crucial for the interaction with NTPDase 1 and is preferentially distributed in human heart tissues [123]. RanBPM is known to interact with Sos and regulate ERK/Ras signaling. NTPDase1 interacts with RanBPM to directly modulate Ras activation and cellular proliferation in liver regeneration following partial hepatectomy [124].

The N-termini of NTPDases also have consensus sequences for protein phosphorylation by protein kinase C [47] that could have additional functional impacts. Furthermore, the C-terminal sequence of NTPDase1 contains a putative PDZ domain (-K-D$\mathrm{M}-\mathrm{V})$. This may have utility in determining interactions with select $\mathrm{P} 2 \mathrm{Y}$ receptors e.g., the purinergic $\mathrm{P}_{2} \mathrm{Y}_{1}$ and $\mathrm{P} 2 \mathrm{Y}_{2}$ receptors that terminate in -D-T-S-L and -D-I-R-L, respectively [125]. PDZ domains are most often found in combination with other protein interaction domains (for instance, SH3, PTB, WW), participating in complexes that facilitate signaling or determine the localization of receptors [126-128].

Finally, the general membrane topography of NTPDase 1 and oligomeric assembly resemble the morphology of channel forming proteins such as $\mathrm{P} 2 \mathrm{X}$ nucleotide receptors and members of the epithelial $\mathrm{Na}^{+}$ channel/degenerin gene superfamily [129]. This raises the question whether, in addition to their catalytic activity, NTPDases could function as channels. Release of ATP from Xenopus oocytes induced by hyperpolarizing pulses requires functional ecto-ATPase activity [130]. To what extent this functional property is shared by the structurally related NTPDase2, NTPDase3 and NTPDase8 has not been investigated.

\section{Vasculature}

The normal vascular endothelium provides a barrier that separates blood cells and plasma factors from highly reactive elements of the deeper layer of vessel wall. The vessel wall maintains blood fluidity and promotes flow by inhibiting coagulation, platelet activation and promoting fibrinolysis [131]. These properties are governed by important thromboregulatory mechanisms; key biological activities of the vasculature have been already identified and shown to be ecto-nucleotide catalysts that generate the respective nucleosides by phosphohydrolysis [19, 82]. The dominant ectonucleotidases of the vasculature have now more fully been characterized as NTPDases. This important biological property expressed by the endothelium and associated cells is responsible for the regulation of extracellular and plasma levels of nucleotides [20, 44, 82, 132, 133].

Over the past decade, extracellular nucleotides have been recognized as important mediators of a variety of processes including vascular inflammation and thrombosis with varying impacts in different systems [19]. Adenosine and ATP mediated effects or mechanisms can be implicated in the local control of vessel tone as well as in individual vascular cell migration, proliferation and differentiation. As an example, ATP may be released from sympathetic nerves (see later sections) and results in constriction of vascular smooth muscle through effects mediated by $\mathrm{P} 2 \mathrm{X}$ receptors. In contrast, ATP released from endothelial cells during changes in flow (shear stress) or following exposure to hypoxic conditions activates $\mathrm{P} 2 \mathrm{Y}$ receptors in a paracrine manner to release NO, resulting in vessel relaxation. Any nucleotide released will be ultimately hydrolyzed to adenosine and will result in vasodilatation via the effects of smooth muscle P1 receptors. $\mathrm{P} 2 \mathrm{X}$ receptors also appear on vascular cells and are associated with changes in cell adhesion and permeability [2]. These cellular processes and nucleotidetriggered events are modulated during angiogenesis (Fig. 4) and influence the development of atherosclerosis and restenosis following angioplasty $[2,113,134$ 136]. 

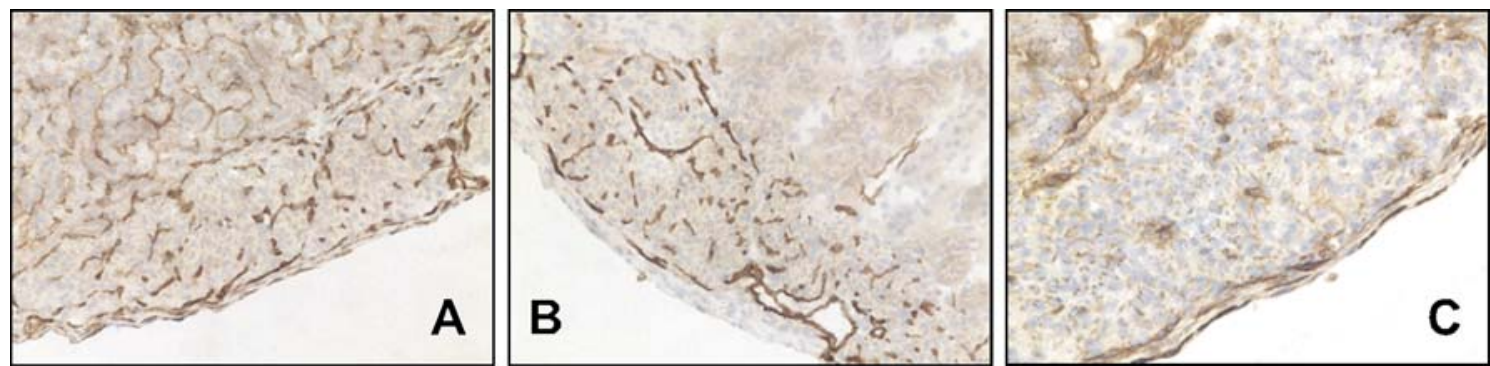

Fig. 4 Angiogenesis with expression of NTPDase1 in the vasculature of syngeneic islet transplants. Mouse islets were prepared from wild type and Entpd1 null mice, as described by T. Maki et al. and transplanted under the renal capsule [261]. Islets were harvested at four weeks ( $n=4$ per group) and stained for NTPDase1 immunoactivity and other markers of EC. Substantially diminished levels of CD31 staining vascular elements were also present in null to Entpd1 null grafts, indicating a defect in new vessel growth (not depicted here). A) Wild type to wild type showing grafted islet vasculature staining for NTPDase1 with adjacent normal renal vascular pattern. B) Wild type to null mouse showing intrinsic vasculature of islet has persisted within the graft and even entered the NTPDase1 null renal parenchyma. C) Null to wild type grafts showing infiltrating macrophages and NTPDase1 positive endothelium migrating from recipient (confirmed by other stains; not shown).

NTPDase1 is the major ectonucleotidase in the vasculature [112]. Other NTPDases associated with the vasculature are the cell-associated NTPDase 2 and the soluble monocyte expressed NTPDase5 [32, 50, 137]. The phosphohydrolytic reaction of NTPDase 1 limits the platelet activation response that is dependent upon the paracrine release of ADP and activation of specific purinergic receptors [81, 132, 138]. In contrast, NTPDase2, a preferential nucleoside triphosphatase, activates platelets by converting the competitive antagonist (ATP) of platelet ADP-receptors to the specific agonist of the $\mathrm{P}_{2} \mathrm{Y}_{1}$, and $\mathrm{P}_{2} \mathrm{Y}_{12}$ receptors. In keeping with these biochemical properties, NTPDase 1 is dominantly expressed by endothelial cells and the associated vascular smooth muscle where it serves as a thromboregulatory factor. In contrast, NTPDase2 is associated with the adventitial surfaces of the muscularized vessels, microvascular pericytes of some tissues and organs as the heart and the stromal cells and would potentially serve as a hemostatic factor [62].

Extracellular nucleotide stimulation of $\mathrm{P} 2$ receptors represents components of platelet, endothelial cell and leukocyte activation that culminate in vascular thrombosis and inflammation in vivo [19]. In these inflammatory settings, with oxidant endothelial injury, NTPDase1 biochemical function is substantially, albeit temporarily, decreased because of post-translational changes; reconstitution of vascular NTPDase activity occurs following transcriptional upregulation of CD39 in endothelium $[82,139]$. This functional change may relate, at least in part, to alterations in acylation and associated membrane lipid association with consequent disruption of multimer structure. Interestingly, palmitate supplementation may protect against loss of NTPDase activity following cellular activation in vitro [81]. These observations may provide several avenues of research to augment NTPDase activity within the vasculature at sites of injury [134].

Mechanisms of endothelial cell activation by nucleotides

ATP and UTP increases intracellular calcium levels, results in cytoskeletal rearrangements and stimulates phosphorylation of several proteins in human endothelial cells (EC) that are also associated with integrin signaling [140-142]. These include the focal adhesion kinase (FAK) and paxillin, proline-rich tyrosine kinase 2 (Pyk2) (also named related adhesion focal tyrosine kinase, RAFTK) and p38 MAP kinase. Further, UTP preferentially increases EC migration in a PI3-kinase and ERK-dependent manner. Moreover, extracellular nucleotide-mediated EC activation involves cytoskeletal rearrangements and increases in cell motility, comparable to that seen with ligation of integrins by extracellular matrix proteins [143]. These phenotypic changes (seen in both nucleotide- and matrix-mediated activation) are associated with tyrosine phosphorylation of FAK, paxillin and p130 Crk-associated substrate $\left(\mathrm{p} 130^{\mathrm{cas}}\right)$ and down-stream activation of $\mathrm{p} 38$ MAP kinases. FAK has been implicated to play an important role in integrin-mediated signal transduction pathways [144], suggesting that P2-receptors are implicated in 'inside-out' integrin signaling in EC, as well as platelets $[20,112]$.

\section{Therapeutic considerations}

To test how extracellular nucleotide-mediated signaling influences pathophysiological events, several techniques have been developed and validated to 
manipulate NTPDase1 expression in the vasculature and to study conditions of inflammatory stress. The first mutant mouse derived and studied concerned the global deletion of the gene encoding the dominant ectonucleotidase NTPDase1 (Entpd1,cd39). The mutant mice exhibit major perturbations of $\mathrm{P} 2$ receptormediated signaling in the vasculature and immune systems [19, 89, 145]. These phenomena manifest as hemostatic defects, thromboregulatory disturbances, heightened acute inflammatory responses with a failure to generate cellular immune responses that are all associated with vascular endothelium, monocyte, dendritic cell and platelet integrin dysfunction [20, 112, 134].

The therapeutic potential of NTPDase1 to regulate $\mathrm{P} 2$ receptor function in the vasculature and mitigate against thrombotic/inflammatory stress has been further established by the generation of NTPDase1 transgenic mice and swine [20, 146], the use of adenoviral vectors to upregulate NTPDase 1 in cardiac grafts [147] and the use of soluble derivatives of NTPDase1 and apyrases [133, 148]. The beneficial effects of administered NTPDases have been determined in several animal models of vascular inflammation [148, 149]. Exogenous infusions of soluble NTPDases are able to rescue Entpd1-deficient mice from systemic toxicity induced by ischemia reperfusion injury and after stroke induction $[145,150]$.

Angiogenesis requires the dynamic interaction of endothelial cell proliferation and differentiation with orchestrated interactions between extracellular matrix and surrounding cells (such as vascular smooth muscle and/or pericytes) [151-153]. NTPDase1 appears crucial in the co-ordination of angiogenic responses in inflammation, organ remodeling and transplantation [20, 134]. For example, in syngeneic pancreatic islet transplantation, the maintenance and revascularization of grafted islets appears dependent upon expression of NTPDase1 by the developing vasculature within the islet (Fig. 4).

In summary, multiple experimental studies largely reveal beneficial effects of over-expression of NTPDases within the vasculature, or by their pharmacological administration [20, 133]. Clinical studies of these soluble thromboregulatory factors are in planning [20, 154, 155].

\section{Immune system}

There are multiple $\mathrm{P} 2 \mathrm{X}$ and $\mathrm{P} 2 \mathrm{Y}$ receptor subtypes expressed by monocytes and dendritic cells, whereas lymphocytes express only P2Y receptors [2]. NTP-
Dase1/CD39 was first described as a B lymphocyte activation marker and also shown to be expressed on activated $\mathrm{T}$ cells [156, 157] and dendritic cells [89]. The CD39 enzymatic function on dendritic cells is involved in the recruitment, activation and polarization of naive $\mathrm{T}$ cells. ATP is released by $\mathrm{CD}^{+}$and $\mathrm{CD}^{+} \mathrm{T}$ cells upon stimulation with $\mathrm{Con} \mathrm{A}$ or antiCD3 mAb while CD39 functions as an additional recognition structure on haptenated target immunocytes for HLA-A1-restricted, hapten-specific cytotoxic T cells [156, 157].

In cd39 null mice, there are major defects in dendritic cell function antigen presentation and T-cell responses to haptens (type IV hypersensitivity reactions) [19, 89]. Immunocyte-associated CD39 may play an immunoregulatory role by hydrolyzing ATP (and perhaps ADP) released by $\mathrm{T}$ cells during antigen presentation and thereby generating adenosine $[19,89$, 158]. Ectoenzymes, including ectonucleotidases, are known to play an important role in leukocyte trafficking (for an excellent review on this topic, see [159]).

Recent work has indicated that regulatory CD4 + ve $\mathrm{CD} 25+$ ve $\mathrm{T}$ cells $\left(\mathrm{T}_{\text {reg }}\right.$ cells) play important roles in the maintenance of immunological reactivity and tolerance [160]. The selective expression of CD39 by $\mathrm{T}_{\text {reg }}$ and the question whether this ectonucleotidase and/or extracellular nucleotides influence(s) the function of these interesting cells is a focus of current work.

\section{Digestive and renal systems}

Released nucleotides are polarized and do not re-enter cells. They have to be transformed into the corresponding nucleosides that enter cells via specific transporters to rebuild nucleoside pools. If this did not occur, they would be lost from the metabolic pool. The same may pertain to dietary ingestion of nucleotides where NTPDases are potential participants in the digestion of exogenous nucleotides and intestinal function. In addition, extracellular nucleotide and adenosine receptors are highly expressed in the digestive and renal systems, so these molecules are likely to have homeostatic functions [2].

An important nucleotide-mediated mechanism that seems common to various epithelia, as well as to hepatocytes, involves the autocrine regulation of cell volume by ATP via P2 receptors $[161,162]$. As P2 receptors are expressed by epithelia in a polarized manner and can be linked to several digestive and homeostatic functions [163, 164], the presence of NTPDases in the immediate environment may serve as regulatory switches. 
Liver

In the liver, extracellular nucleotides are potentially involved in several functional contexts [161]. There is evidence that extracellular nucleotides regulate glycogenolysis through activation of glycogen phosphorylase and inactivation of glycogen synthase by inhibition of the glucagon effect on cAMP and by the activation of phospholipase D [165, 166]. In addition, nucleotides may be involved in the regulation of canalicular contraction and bile flow [167-169]. Concentrations of canalicular adenine nucleotides in bile samples and effluents from hepatic cell lines are estimated to be around 0.1 to $5 \mu \mathrm{M}[161,168]$. Hepatocytes and bile duct cells have been shown to interact and communicate via local ATP release in vitro [170]. Extracellular ATP acts as a hepatic mitogen and activates JNK signaling and hepatocyte proliferation both in vitro and in vivo [171].

Several ectonucleotidases are expressed in liver. Of the nucleotide pyrophosphatase/phosphodiesterases, NPP1 (PC-1) is expressed on the basolateral membrane of hepatocytes while the closely related NPP3 (B10) has a predominant canalicular in distribution [172, 173]. NTPDase1 is highly expressed on larger vessels and more weakly on sinusoids as well as in Kupffer cells [174]. In the quiescent liver, NTPDase 2 is expressed by cells of the subendothelium of veins and adventitial cells of arteries, but not in sinusoids. In addition, NTPDase2 is expressed by portal fibroblasts near basolateral membranes of bile duct epithelia [175]. Activated but not quiescent hepatic stellate cells express NTPDase2 at the protein level [176]. Only low expression of NTPDase 3 could be demonstrated at the mRNA level in the liver [50, 177].

NTPDase2 expression in portal fibroblasts, the primary fibroblastic cell type of the portal area, suggests a role in the regulation of bile ductular signaling and secretion [161, 175]. Jhandier et al. tested the hypothesis that portal fibroblast NTPDase 2 regulates epithelial cell proliferation. Using co-cultures of cholangiocytes (Mz-ChA-1 human cholangiocarcinoma cells) and primary portal fibroblasts from rat liver, increased NTPDase 2 expression decreased cell proliferation, and knockdown of NTPDase 2 by siRNA increased proliferation. P2 receptor blockade also attenuated Mz-ChA-1 proliferation [117]. These experiments defined a novel cross-talk signaling pathway between bile duct epithelial cells and underlying portal fibroblasts, regulated by NTPDase2. Because they are the chief fibrogenic cells of the liver, hepatic stellate cells and portal fibroblasts are important targets of liver disease therapy. Loss of NTPDase2 expression in human biliary cirrhosis, as well as in models of bile duct ligation in rat, has been observed. NTPDase2 expression also shifts from the portal area to bridging fibrous bands in cirrhosis with hepatitis C [99].

Functional ATPases were previously shown to be associated with bile canalicular plasma membranes by histochemical techniques [178]; the corresponding enzyme was subsequently incorrectly identified as cCAM105 [179-181]. More recent studies revealed that the canalicular ecto-ATPase corresponds to NTPDase8 [52], also referred to as hepatic ATP diphosphohydrolase (ATPDase) [174, 182]. NTPDase8 is the mammalian orthologue of the chicken ectoATPDase cloned from oviduct and liver [183, 184]. In tandem with ecto-5'-nucleotidase, NTPDase 8 has the potential to regulate the concentration of nucleotides in the hepatic canalicule. The ultimate generation of extracellular adenosine from dephosphorylated ATP not only activates adenosine receptors but also produces the key molecule for purine salvage and consequent replenishment of ATP stores within many cell types [17, 185]. Adenosine transporters are of major importance to organs and cells incapable of de novo nucleotide synthesis such as brain, muscle, intestinal mucosa and bone marrow $[167,186]$. As the liver appears to be a major source of purines for these tissues, curtailment of nucleotide loss into the bile may be important to maintain appropriate nucleotide/ nucleoside concentrations within hepatocytes [185]. Thus, dephosphorylation of nucleotides by ectonucleotidases may be critical for appropriate systemic purine homeostasis [167]. The presence of NTPDase8, ecto5 -nucleotidase and nucleoside transporters in the canalicular domain of hepatocytes would be consistent with an important role of NTPDase8 in purine salvage.

\section{The exocrine pancreas}

The exocrine pancreas secretes digestive enzymes and a $\mathrm{HCO}_{3}$-rich fluid. Acini release ATP and the excurrent ducts express several types of $\mathrm{P} 2$ receptors [187, 188]. Thus ATP may function as a paracrine mediator between pancreatic acini and ducts. Ectonucleotidase activity in pancreatic tissues was first detected in the rat in the 1960s [189, 190], followed by analyses in the pig [191, 192]. Cytochemical and biochemical observations have corroborated the association of ATPase activity with zymogen granules [193]. In other studies of small intercalated/interlobular ducts, NTPDase1 immuno-fluorescence can be localized on the luminal membranes, while in larger ducts it is localized on the basolateral membranes [194]. Upon stimulation with 
cholecystokinin octapeptide-8 (CCK-8), acinar NTPDase1 relocalized in clusters towards the lumen and is secreted into the pancreatic juice, as an active form associated with particulate fractions [188, 195]. As revealed by electron microscopy, NTPDase2 is located on epithelial cells, myoepithelial cells and the basolateral membrane of acini. Interestingly, NTPDase2 could be also detected at the basolateral surface of endothelial cells [194].

Salivary glands

There are only few studies on the localization of NTPDases in salivary glands. NTPDases might play a role in the transport of electrolytes by modulating the extracellular ATP concentration in the salivary gland ducts. NTPDase1 reveals to be mainly vascular in expression. NTPDase2 was immunodetected on myoepithelial cells and in nerves [194, 196]. The immunolocalization of NTPDases 3 and 8 in salivary glands has not yet been determined.

\section{Kidney}

The kidney reveals a complex cellular profile of expression for $\mathrm{P} 1$ and $\mathrm{P} 2$ receptors as well as of ectonucleotidases. Both ATP and adenosine have been invoked in the regulation of tubuloglomerular feedback [197, 198]. This feedback system links the salt concentrations in the tubular fluid at the macula densa to the vascular tone of the afferent arteriole of the same nephron. As depicted by their localization, NTPDases may participate in the regulation of several biological functions of the kidney, including vascular perfusion. In mouse, rat and porcine kidneys, NTPDase1 can be detected in vascular structures, including blood vessels of glomerular and peritubular capillaries $[174,199,200]$. NTPDase 2 is detected on the Bowman's capsules of mouse and rat [199] and NTPDase8 on the luminal side of porcine renal tubules [174]. More recently, an immunohistochemical analysis of various ectonucleotidases of the rat nephron revealed expression of both NTPDase 2 and NTPDase 3 in the thick ascending limb, the distal tubule and the inner medullary collecting ducts. In addition, NTPDase 3 is located in the cortical and outer medullary collecting ducts [201].

\section{The nervous system}

All cell types of the nervous system express nucleotide receptors [2]. It is increasingly apparent that NTP-
Dases are distributed in the nervous system as ubiquitously as are $\mathrm{P} 2$ receptors and that these ectoenzymes are directly involved in the control of $\mathrm{P} 2$ receptor function in nervous tissues [22, 31, 36]. Signaling via nucleotides is widespread both in the peripheral and central nervous system. Major nucleotide receptormediated functions in the central nervous system include the modulation of synaptic signal transmission [202], the propagation of $\mathrm{Ca}^{2+}$ waves between glial cells [203], or the control and activation of astrocytes and microglia [204, 205]. In addition, ATP can contribute to synaptic signal transmission [36]. In the sympathetic nervous system, ATP acts as a fast neurotransmitter together with catecholamines [206], it is an important mediator of central and peripheral chemosensory transduction, including pain [207] and it is involved in the control of myelination formation of peripheral axons [208].

\section{Central nervous system}

ATP can be rapidly hydrolyzed to adenosine at brain synapses that in turn activates pre- or postsynaptic receptors, thereby modulating neuronal transmission. Adenine nucleotides undergo conversion to adenosine within a few hundred milliseconds in the extracellular (synaptic) space of rat brain slices [209, 210]. Complex synaptic interactions in the central nervous system may thus be modulated both by the activation of P2 and (after hydrolysis of the nucleotide) P1 receptors that may be located at identical or different cellular targets [202, 211].

Based on immunoblotting and in situ hybridization, NTPDase1, 2 and 3 are expressed in the mammalian brain [47, 57, 59, 116, 177, 212]. NTPDase1 and 2 have been purified from porcine brain [213, 214]. But the exact cellular allocation of individual subtypes is still a challenge. There is ample evidence from early enzyme histochemical investigations that surface-located catalytic activity for the hydrolysis of nucleoside tri- and diphosphates can be allocated to all cell types of the nervous system [for reviews see 22, 31, 36, 215]. This catalytic activity can be localized to synapses, including the synaptic cleft, at the surface of neurosecretory nerve terminals in the pituitary or at peripheral nerve terminals. These data imply a wide distribution of cell surface-located ATP hydrolyzing activity in the CNS.

\section{Neurons}

Ecto-ATPase activity has been observed in synaptosomal fractions isolated from various sources, implying 
endogenous ectonucleotidase activity of nerve cells. Biochemical studies on isolated synaptosomes permit the determination of the ratios of ATP to ADP hydrolysis rates as well as the analysis of product formation. Total synaptosome fractions isolated from rat brain cortex and immunopurified cholinergic striatal synaptosomes revealed ratios of 3.4: 1 and 2.1: 1, respectively [216]. ADP was found to transiently accumulate after addition of ATP, and was subsequently metabolized to AMP and adenosine. Similar results were obtained with hippocampal synaptosomes [217]. This strongly argues against a major contribution by NTPDase 1 and NTPDase2 and would rather be compatible with a neuronal expression of NTPDase3 (comp. Fig. 2). A recent immunocytochemical study allocates NTPDase3 to neurons including axon-like structures of various brain regions [218].

Astrocytes, oligodendrocytes, and microglia

The ratio of ATP to ADP hydrolysis is clearly different in cultured astrocytes. Astrocytes cultured from cortex or hippocampus display a ratio of $8: 1$ [219]. Furthermore, cultured rat cortical astrocytes accumulate ADP from ATP that is only very slowly further degraded to AMP [220]. This would be largely compatible with NTPDase 2 as the major ectonucleotidase of cultured astrocytes. Immunocytological investigations of adult rat and mouse brain sections assign NTPDase2 solely to the astrocyte-like stem cells in the subventricular zone of the lateral ventricles and the dentate gyrus of the hippocampus and to astrocytes in few distinct additional brain regions [221, 222]. Thus, cultured astrocytes may reveal functional properties that differ from the in situ situation as they tend to rapidly alter their protein expression profile [223].
Enzyme histochemistry assigns ecto-ATPase activity to both central and peripheral myelin [31], but fully supplementary immunocytochemical data are lacking. Enzyme histochemical staining for surface-located nucleoside diphosphate activity has long been used to identify microglia in tissue sections of the adult and developing brain [224]. The major microglial ectonucleotidase has been identified as NTPDase1 [225].

\section{Stem cells in the adult mammalian brain}

In the adult rodent brain, neurogenesis persists in two restricted regions, the subventricular zone (SVZ) of the lateral ventricles and the dentate gyrus of the hippocampus. These regions contain stem cells that give rise to neurons throughout the life span of the animal. Interestingly, these cells share astrocytic properties [226]. They generate highly proliferating intermediate cell types and finally mature neurons. NTPDase2 is highly and selectively expressed by the stem cells (type B cells) of the SVZ [221] (Fig. 5) as well as by the progenitor cells (residual radial glia) of the dentate gyrus [222]. In the presence of epidermal growth factor (EGF) and fibroblast growth factor-2 (FGF-2), SVZ-derived stem cells can be cultured as free floating cellular aggregates (neurospheres). Cultured stem cells express NTPDase2 and functional P2 receptors. Agonists of $\mathrm{P}_{2} \mathrm{Y}_{1}$ and $\mathrm{P} 2 \mathrm{Y}_{2}$ receptors augment cell proliferation, whereas inhibition of the receptors attenuates cell proliferation in spite of the presence of mitogenic growth factors [227]. These data suggest that NTPDase 2 and nucleotides, together with other signaling pathways, contribute to the control of neurogenesis in the adult mammalian brain.

Apparently, individual enzyme isoforms govern cell surface-located nucleotide hydrolysis in the various cell
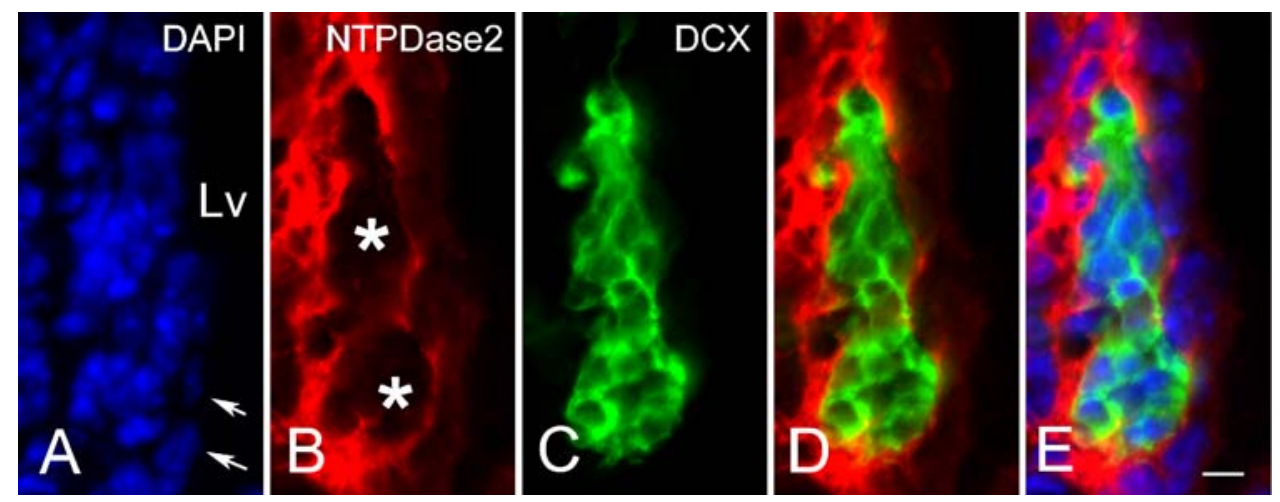

Fig. 5 Detail of arrangement of neuronal stem cells and neuroblasts at the lateral lining of the mouse subventricular zone (SVZ) (triple labeling). A) DAPI staining of all nuclei. Arrow heads mark endymal lining. B) Stem cells (type B cells) immunopositive for NTPDase2 form tube-like sheeths around clusters of migrating immature neurons (type A cells) that immunostain for the microtubule-associated protein doublecortin (DCX) (C). The spaces covered by type A cells remain dark in (B) and are indicated with stars. D) Merge of B) and C). E) Merge of A), B) and C). Bar = $10 \mu \mathrm{m}$. (by courtesy of David Langer, Frankfurt am Main). 
types of the central nervous system. This does not exclude however, the possibility that individual cell types express more than one isoform with one of the enzymes predominating. For example, PC12 cells express mRNA for NTPDase1-3. But the ATP/ADP hydrolysis ratio, the pattern of product formation and the immunocytochemical surface staining suggest that NTPDase3 is the major functional isoform [59, 228]. Similarly cultured normal and immortalized pituitary and hypothalamic cells express NTPDase1-3 [116]. The future planned use of transgenic mice expressing fluorescent protein under the promoter of the respective NTPDase isoform will greatly facilitate the identification of the expression pattern of individual enzyme isoforms in the developing and adult nervous system.

\section{Peripheral nervous system}

Noradrenaline and ATP are co-released from sympathetic nerve terminals of the guinea pig heart whereby ATP enhances noradrenaline release by a mechanism controlled by ectonucleotidases, possibly NTPDase1 [229]. Interestingly, stimulated sympathetic nerves of the guinea pig vas deferens release not only ATP and noradrenaline but also enzyme activity that degrades ATP to adenosine. The latter exhibits similarities to NTPDases and ecto-5'-nucleotidase but their molecular identity has not been defined [230].

NTPDase 2 associates with immature and non-myelinating Schwann cells of peripheral nerves whereas NTPDase1 immunoreactivity is absent [231]. NTPDase2 is also expressed by the satellite glial cells in dorsal root ganglia and sympathetic ganglia and by the enteric glia surrounding cell bodies of ganglionic neurons of the myenteric and submucous plexus [231].

\section{Sensory systems}

The most comprehensive investigation of expression of NTPDases within sensory systems concerns the inner ear. Ectonucleotidase activity is associated with the tissues lining the perilymphatic compartment of the cochlea [232, 233]. Immunohistochemical analysis of the murine cochlea has assigned NTPDase1 to the cochlear vasculature and primary auditory neurons in the spiral ganglion, whereas NTPDase2 is associated with synaptic regions of the sensory inner and outer hair cells, supporting cells of the organ of Corti and additional tissue elements [234, 235]. Interestingly, noise exposure induces upregulation of NTPDase1 and NTPDase2 in the rat cochlea [236].
Taste buds transduce chemical signals in the mouth into neural messages. Taste cells and nerve fibers express $\mathrm{P}_{2} \mathrm{X}_{2}$ and $\mathrm{P} 2 \mathrm{X}_{3}$ receptors [237] and various $\mathrm{P} 2 \mathrm{Y}$ receptors $[238,239]$. Genetic elimination of $\mathrm{P} 2 \mathrm{X}_{2}$ and $\mathrm{P} 2 \mathrm{X}_{3}$ receptors revealed that ATP is a key neurotransmitter in this system [240]. NTPDase2 is expressed at the mRNA level in mouse taste papillae [241]. Immunohistochemistry and enzyme histochemical staining allocate NTPDase2 to type I 'glial-like' cells in the tongue, palate and larynx. Furthermore, NTPDase2 immunostaining is associated with nearby nerves, suggestive of Schwann cells, implying that NTPDase2 may be a regulator in defined taste transmission.

\section{Pathological implications}

Cerebral ischemia

The interruption of blood flow accompanied by an interrupted supply of oxygen and glucose initiates a sequence of events resulting in structural and functional damage of the nervous tissue, comparable to that seen at other sites of vascular injury [20]. Transient global cerebral ischemia of the rat results in a long-term increase in extracellular nucleotide hydrolysis pathways [242, 243]. Preconditioning delays the postischemic increase in ATP diphosphohydrolase activity [243]. During the days following transient forebrain ischemia, mRNA for NTPDase1 (but not of NTPDase2) and ecto-5'-nucleotidase becomes upregulated in the hippocampus [242], corresponding to the upregulation of the entire ectonucleotidase chain for the hydrolysis of ATP to adenosine. The data suggest that the increased expression of ectonucleotidases in the regions of damaged nerve cells is associated with activated glia, mainly microglia [224].

The upregulation of the ectonucleotidase chain is suggestive of an ischemia-induced increased and sustained cellular release of nucleotides. This could have several functional implications. Since microglial cells express the cytolytic $\mathrm{P}_{2} \mathrm{X}_{7}$ receptor $[244,245]$ the activity of these cells may be particularly endangered by increased levels of extracellular ATP. Enhanced activity of NTPDase1 may prevent activated microglia from overstimulation by ATP released from the injured tissue. Alternatively, microglial expression of NTPDase1 might contribute to preventing receptor desensitization on prolonged exposure to elevated ATP levels. The parallel increase in activity of ecto$5^{\prime}$-nucleotidase would facilitate the formation of the final hydrolysis product adenosine that exerts neuro- 
modulatory and immunomodulatory actions and contributes to the protection of neurons.

Alterations following plastic changes in the nervous system

Additional experiments, analyzing synaptosome fractions, suggest that changes in neural plasticity can be paralleled by changes in ecto-ATPase activity. Enzyme activity is reduced following avoidance learning [246] and status epilepticus [247, 248]. It is altered in two rat models of temporal lobe epilepsy [249], and on pentylenetetrazol kindling [250]. Changes in synaptosomal ectonucleotidase activity have been implicated by a broad variety of additional treatments including acute caffeine treatment [251]. Taken together, these experiments suggest that expression of ectonucleotidases can be altered following a variety of physiological or pathological stimuli, possibly together with that of purine receptors. Further work needs to define the enzyme subtypes involved and the mechanisms underlying the regulation of ectonucleotidase expression.

\section{Conclusions}

This review summarizes components of extracellular nucleotide-mediated signaling pathways that are impacted upon largely by the E-NTPDase family of ectonucleotidases. Modulated, distinct NTPDase expression appears to regulate nucleotide-mediated signaling in essentially every tissue, including the vasculature and of immune and nervous systems. For example, extracellular nucleotide-mediated vascular endothelial and accessory cell stimulation might have important consequences for platelet activation, thrombogenesis, angiogenesis, vascular remodeling and the metabolic milieu of the vasculature, in response to inflammatory stress and/or immune reactions.

Nucleotides are also of significant relevance for the communication of nerve cells and glial cells or in the reciprocal signaling between these cells. These purinergic mechanisms might also dictate pathological processes of the nervous system or following vascular injury, thromboregulatory disturbances, and defective angiogenesis with associated perturbations in tissue remodeling and regeneration.

There is a wide field for future investigations of the role of nucleotides and ectonucleotidases in other tissues. Increasing interest in this field may open up new avenues for investigation and the development of new treatment modalities for a large variety of diseases, including neurological pathological states, vascular thrombotic disorders including stoke, atherosclerosis and the vascular inflammation seen in transplant-graft failure.

Acknowledgements This work was supported by the Deutsche Forschungsgemeinschaft (140/17-1; GRK 361; to HZ); NIH HL57307, HL63972 and HL076540 (to SCR), and the Canadian Institutes of Health Research (CIHR; to JS). JS is also a recipient of a New Investigator award from the CIHR.

\section{References}

1. Luthje J (1989) Origin, metabolism and function of extracellular adenine nucleotides in the blood. Klin Wochenschr 67:317-327

2. Burnstock G, Knight GE (2004) Cellular distribution and functions of $\mathrm{P} 2$ receptor subtypes in different systems. Int Rev Cytol 240:31-304

3. Lazarowski ER (2003) Molecular and biological properties of P2Y receptors. In: Schwiebert EM (ed) Extracellular Nucleotides and Nucleosides: Release, Receptors, and Physiological and Pathophysiological Effects. Academic, Amsterdam, Boston, pp 59-96

4. Harden TK, Lazarowski ER, Boucher RC (1997) Release, metabolism and interconversion of adenine and uridine nucleotides: Implications for $\mathrm{G}$ protein-coupled $\mathrm{P} 2$ receptor agonist selectivity. Trends Pharmacol Sci 18:43-46

5. Weisman GA, Erb L, Garrad RC et al (1998) P2Y nucleotide receptors in the immune system: Signaling by a $\mathrm{P}_{2} \mathrm{Y}_{2}$ receptor in U937 monocytes. Drug Dev Res 45:222-228

6. Erlinge D, You JP, Wahlestedt C et al (1995) Characterisation of an ATP receptor mediating mitogenesis in vascular smooth muscle cells. Eur J Pharmacol-Molec Pharm 289:135-149

7. Erlinge D (1998) Extracellular ATP: A growth factor for vascular smooth muscle cells. Gen Pharmacol 31:1-8

8. Hou MY, Harden TK, Kuhn CM et al (2002) UDP acts as a growth factor for vascular smooth muscle cells by activation of $\mathrm{P}_{2} \mathrm{Y}_{6}$ receptors. Am J Physiol Heart Circ Physiol 282:H784-H792

9. Sasamura H, Dza VJ, Pratt RE (1994) Desensitization of angiotensin receptor function. Kidney Int 46:1499-1501

10. Goding JW, Howard MC (1998) Ecto-enzymes of lymphoid cells. Immunol Rev 161:5-10

11. Abbracchio MP, Burnstock G (1994) Purinoceptors: Are there families of $\mathrm{P}_{2 \mathrm{X}}$ and $\mathrm{P}_{2 \mathrm{Y}}$ purinoceptors? Pharmacol Ther 64:445-475

12. Dubyak GR, El-Moatassim C (1993) Signal transduction via P2 purinergic receptors for extracellular ATP and other nucleotides. Am J Physiol 265:C577-C606

13. Fredholm BB, Abbracchio MP, Burnstock G et al (1994) Nomenclature and classification of purinoceptors. Pharmacol Rev 46:143-156

14. Palmer TM, Stiles GL (1995) Adenosine receptors. Neuropharmacology 34:683-94

15. Buell G, Collo G, Rassendren F (1996) P2X receptors: An emerging channel family. Eur J Neurosci 8:2221-2228

16. Roman RM, Fitz JG (1999) Emerging roles of purinergic signalling in gastrointestinal epithelial secretion and hepatobiliary function. Gastroenterology 116:964-979

17. Plesner L (1995) Ecto-ATPases: Identities and functions. Int Rev Cytol 158:141-214 
18. Zimmermann H (1996) Extracellular purine metabolism. Drug Dev Res 39:337-352

19. Robson SC, Enjyoji K, Goepfert C et al (2001) Modulation of extracellular nucleotide-mediated signaling by CD39/ nucleoside triphosphate diphosphohydrolase-1. Drug Dev Res 53:193-207

20. Robson SC, Wu Y, Sun XF et al (2005) Ectonucleotidases of CD39 family modulate vascular inflammation and thrombosis in transplantation. Semin Thromb Hemost 31: 217-233

21. Goding JW (2000) Ecto-enzymes: Physiology meets pathology. J Leukoc Biol 67:285-311

22. Zimmermann H (2001) Ecto-nucleotidases. In: Abbracchio MP, Williams M (eds) Handbook of experimental pharmacology. Purinergic and pyrimidergic signalling. Springer, Berlin Heidelberg New York, pp 209-250

23. Moser TL, Kenan DJ, Ashley TA et al (2001) Endothelial cell surface $F_{1}-F_{o}$ ATP synthase is active in ATP synthesis and is inhibited by angiostatin. Proc Natl Acad Sci USA 98:6656-6661

24. Arakaki N, Nagao T, Niki R et al (2003) Possible role of cell surface $\mathrm{H}^{+}$-ATP synthase in the extracellular ATP synthesis and proliferation of human umbilical vein endothelial cells. Mol Cancer Res 1:931-939

25. Stefan C, Jansen S, Bollen M (2005) NPP-type ectophosphodiesterases: Unity in diversity. Trends Biochem Sci 30:542-550

26. Zimmermann H (1992) 5'-nucleotidase-molecular structure and functional aspects. Biochem J 285:345-365

27. Resta R, Yamashita Y, Thompson LF (1998) Ecto-enzyme and signaling functions of lymphocyte CD73. Immunol Rev 161:95-109

28. Burch LH, Picher M (2006) E-NTPDases in human airways regulation and relevance for chronic lung diseases. Purinergic Signalling (PUSI 2:1; this issue)

29. Grinthal A, Guidotti G (2006) CD39, NTPDase1, is attached to the plasma membrane by two transmembrane domains. Why? Purinergic Signalling (PUSI 2:1; this issue)

30. Kirley TL, Crawford PA, Smith TM (2006) The structure of the nucleoside triphosphate diphosphohydrolases (NTP Dases) as revealed by mutagenic and comptational modeling analyses. Purinergic Signalling (PUSI 2:1; this issue)

31. Zimmermann H (1996) Biochemistry, localization and functional roles of ecto-nucleotidases in the nervous system. Prog Neurobiol 49:589-618

32. Zimmermann H (1999) Two novel families of ecto-nucleotidases: Molecular structures, catalytic properties, and a search for function. Trends Pharmacol Sci 20:231-236

33. Zimmermann H (2000) Extracellular metabolism of ATP and other nucleotides. Naunyn-Schmiedeberg's Arch Pharmacol 362:299-309

34. Zimmermann H (2001) Ectonucleotidases: Some recent developments and a note on nomenclature. Drug Dev Res $52: 44-56$

35. Wang TF, Handa M, Guidotti G (1998) Structure and function of ectoapyrase (CD39). Drug Dev Res 45:245-252

36. Zimmermann H, Braun N (1999) Ecto-nucleotidases: Molecular structures, catalytic properties, and functional roles in the nervous system. Prog Brain Res 120:371-385

37. Pearson JD (1985) Ectonucleotidases. Measurememt of activities and use of inhibitors. In: Paton DM (ed) Methods in pharmacology 6. Plenum, New York, pp 83-107

38. Ziganshin AU, Hoyle CHV, Burnstock G (1994) Ectoenzymes and metabolism of extracellular ATP. Drug Dev Res 32:134-146
39. Beaudoin AR, Sévigny J, Picher M (1996) ATP-diphosphohydrolases, apyrases, and nucleotide phosphohydrolases: Biochemical properties and functions. In: Lee AG (ed) Biomembranes. JAI, Greenwich, London, pp 369-401

40. Zimmermann H, Pearson J (1998) Extracellular metabolism of nucleotides and adenosine in the cardiovascular system. In: Burnstock G, Dobson JG, Liang BT et al (eds) Cardiovascular Biology of Purines. Kluwer, Dordrecht, Boston, London, pp 342-358

41. Maliszewski CR, DeLepesse GJT, Schoenborn MA et al (1994) The CD39 lymphoid cell activation antigen: Molecular cloning and structural characterization. J Immunol 153:3574-3583

42. Handa M, Guidotti G (1996) Purification and cloning of a soluble ATP-diphosphohydrolase (apyrase) from potato tubers (Solanum tuberosum). Biochem Biophys Res Commun 218:916-923

43. Wang TF, Guidotti G (1996) CD39 is an ecto- $\left(\mathrm{Ca}^{2+}, \mathrm{Mg}^{2+}\right)$ apyrase. J Biol Chem 271:9898-9901

44. Kaczmarek E, Koziak K, Sévigny J et al (1996) Identification and characterization of CD39 vascular ATP diphosphohydrolase. J Biol Chem 271:33116-33122

45. Christoforidis S, Papamarcaki T, Galaris D et al (1995) Purification and properties of human placental ATP diphosphohydrolase. Eur J Biochem 234:66-74

46. Wang TF, Rosenberg PA, Guidotti G (1997) Characterization of brain ecto-apyrase: Evidence for only one ectoapyrase (CD39) gene. Mol Brain Res 47:295-302

47. Kegel B, Braun N, Heine P et al (1997) An ecto-ATPase and an ecto-ATP diphosphohydrolase are expressed in rat brain. Neuropharmacology 36:1189-1200

48. Kirley TL (1997) Complementary DNA cloning and sequencing of the chicken muscle ecto-ATPase-homology with the lymphoid cell activation antigen CD39. J Biol Chem 272:1076-1081

49. Chadwick BP, Frischauf AM (1997) Cloning and mapping of a human and mouse gene with homology to ecto-ATPase genes. Mamm Genome 8:668-672

50. Chadwick BP, Frischauf AM (1998) The CD39-like gene family: Identification of three new human members (CD39L2, CD39L3, and CD39L4), their murine homologues, and a member of the gene family from Drosophila melanogaster. Genomics 50:357-367

51. Chadwick BP, Williamson J, Sheer D et al (1998) cDNA cloning and chromosomal mapping of a mouse gene with homology to NTPases. Mamm Genome 9:162-164

52. Bigonnesse F, Lévesque SA, Kukulski F et al (2004) Cloning and characterization of mouse nucleoside triphosphate diphosphohydrolase-8. Biochemistry USA 43:5511-5519

53. Wang CJF, Vlajkovic SM, Housley GD et al (2005) Cterininal splicing of NTPDase2 provides distinctive catalytic properties, cellular distribution and enzyme regulation. Biochem J 385:729-736

54. Mateo J, Kreda S, Henry CE et al (2003) Requirement of Cys(399) for processing of the human ecto-ATPase (NTPDase2) and its implications for determination of the activities of splice variants of the enzyme. J Biol Chem 278:39960-39968

55. Zola H, Swart B, Nicholson I et al (2005) CD molecules 2005: human cell differentiation molecules. Blood 106: 3123-3126

56. Zimmermann H, Beaudoin AR, Bollen M et al (2000) Proposed nomenclature for two novel nucleotide hydrolyzing enzyme families expressed on the cell surface. In: 
vanDuffel L, Lemmens R (eds) Ecto-ATPases and related ectonucleotidases, Shaker BV, Maastricht, pp 1-8

57. Kukulski F, Lévesque SA, Lavoie ÉG et al (2005) Comparative hydrolysis of $\mathrm{P} 2$ receptor agonists by NTPDase 1, 2, 3 and 8. Purinergic Signalling 1:193-204

58. Lavoie ÉG, Kukulski F, Lévesque SA et al (2004) Cloning and characterization of mouse nucleoside triphosphate diphosphohydrolase-3. Biochem Pharmacol 67:1917-1926

59. Vorhoff T, Zimmermann H, Pelletier J et al (2005) Cloning and characterization of the ecto-nucleotidase NTPDase3 from rat brain: Predicted secondary structure and relation to members of the E-NTPDase family and actin. Purinergic Signaling 1:259-270

60. Heine P, Braun N, Sévigny J et al (2001) The C-terminal cysteine-rich region dictates specific catalytic properties in chimeras of the ecto-nucleotidases NTPDase1 and NTPDase2. Eur J Biochem 262:102-107

61. Grinthal A, Guidotti G (2004) Dynamic motions of CD39 transmembrane domains regulate and are regulated by the enzymatic active site. Biochemistry USA 43:13849-13858

62. Sévigny J, Sundberg C, Braun N et al (2002) Differential catalytic properties and vascular topography of murine nucleoside triphosphate diphosphohydrolase 1 (NTPDase1) and NTPDase2 have implications for thromboregulation. Blood 99:2801-2809

63. Vasconcelos EG, Ferreira ST, de Carvalho TMU et al (1996) Partial purification and immunohistochemical localization of ATP diphosphohydrolase from Schistosoma mansoni - Immunological cross-reactivities with potato apyrase and Toxoplasma gondii nucleoside triphosphate hydrolase. J Biol Chem 271:22139-22145

64. Schulte am Esch J, Sévigny J, Kaczmarek E et al (1999) Structural elements and limited proteolysis of CD39 influence ATP diphosphohydrolase activity. Biochemistry USA 38:2248-2258

65. Smith TM, Kirley TL (2000) Expression, characterization, and site-directed mutagenesis of a human E-type ATPase. In: vanDuffel L, Lemmens $\mathrm{R}$ (eds) Ecto-ATPases and Related Ectonucleotidases. Shaker BV, Maastricht, pp. 90105

66. Hicks-Berger CA, Yang F, Smith TM et al (2001) The importance of histidine residues in human ecto-nucleoside triphosphate diphosphohydrolase-3 as determined by sitedirected mutagenesis. BBA Protein Struct Mol Enzym 1547:72-81

67. Yang F, Hicks-Berger CA, Smith TM et al (2001) Sitedirected mutagenesis of human nucleoside triphosphate diphosphohydrolase 3: The importance of residues in the apyrase conserved regions. Biochemistry USA 40:39433950

68. Murphy DM, Kirley TL (2003) Asparagine 81, an invariant glycosylation site near apyrase conserved region 1 , is essential for full enzymatic activity of ecto-nucleoside triphosphate diphosphohydrolase 3. Arch Biochem Biophys 413:107-115

69. Flaherty KM, Mckay DB, Kabsch W et al (1991) Similarity of the three dimensional structures of actin and the ATPase fragment of a 70-kDa heat shock cognate protein. Proc Natl Acad Sci U S A 88:5041-5045

70. Smith TM, Kirley TL (1999) Site-directed mutagenesis of a human brain ecto-apyrase: Evidence that the E-type ATPases are related to the actin/heat shock 70/sugar kinase superfamily. Biochemistry USA 38:321-328

71. Ivanenkov VV, Murphy-Piedmonte DM, Kirley TL (2003) Bacterial expression, characterization, and disulfide bond determination of soluble human NTPDase6 (CD39L2) nucleotidase: Implications for structure and function. Biochemistry USA 42:11726-11735

72. Ivanenkov VV, Meller J, Kirley TL (2005) Characterization of disulfide bonds in human nucleoside triphosphate diphosphohydrolase 3 (NTPDase3): Implications for NTPDase structural modeling. Biochemistry USA 44:89989012

73. Stout JG, Kirley TL (1996) Control of cell membrane ecto-ATPase by oligomerization state: Intermolecular cross-linking modulates ATPase activity. Biochemistry USA 35: 8289-8298

74. Carl SAL, Smith TM, Kirley TL (1998) Cross-linking induces homodimer formation and inhibits enzymatic activity of chicken stomach ecto-apyrase. Biochem Mol Biol Int 44:463-470

75. Wang TF, Ou Y, Guidotti G (1998) The transmembrane domains of ectoapyrase (CD39) affect its enzymatic activity and quaternary structure. J Biol Chem 273:24814-24821

76. Smith TM, Kirley TL (1999) Glycosylation is essential for functional expression of a human brain ecto-apyrase. Biochemistry USA 38:1509-1516

77. Grinthal A, Guidotti G (2000) Substitution of His59 converts CD39 into an ADPase in a quarternary structure dependent manner. Biochemistry USA 39:9-16

78. Failer BU, Aschrafi A, Schmalzing G et al (2003) Determination of native oligomeric state and substrate specificity of rat NTPDase1 and NTPDase2 after heterologous expression in Xenopus oocytes. Eur J Biochem 270:18021809

79. Grinthal A, Guidotti G (2002) Transmembrane domains confer different substrate specificities and adenosine diphosphate hydrolysis mechanisms on CD39, CD39L1, and chimeras. Biochemistry USA 41:1947-1956

80. Bork P, Sander C, Valencia A (1992) An ATPase domain common to prokaryotic cell cycle proteins, sugar kinases, actin, and hsp70 heat shock protein. Proc Natl Acad Sci USA 89:7290-7294

81. Robson SC, Kaczmarek E, Siegel JB et al (1997) Loss of ATP diphosphohydrolase activity with endothelial cell activation. J Exp Med 185:153-163

82. Robson SC, Daoud S, Begin M et al (1997) Modulation of vascular ATP diphosphohydrolase by fatty acids. Blood Coagul Fibrinolysis 8:21-27

83. Zhong XT, Malhotra R, Woodruff R et al (2001) Mammalian plasma membrane ecto-nucleoside triphosphate diphosphohydrolase $1, \mathrm{CD} 39$, is not active intracellularly The $N$-glycosylation state of CD39 correlates with surface activity and localization. J Biol Chem 276:41518-41525

84. Koziak K, Kaczmarek E, Kittel A et al (2000) Palmitoylation targets CD39/endothelial ATP diphosphohydrolase to caveolae. J Biol Chem 275:2057-2062

85. Kittel A, Kaczmarek E, Sévigny J et al (1999) CD39 as a caveolar-associated ectonucleotidase. Biochem Biophys Res Commun 262:596-599

86. Papanikolaou A, Papafotika A, Murphy C et al (2005) Cholesterol-dependent lipid assemblies regulate the activity of the ecto-nucleotidase CD39. J Biol Chem 280:2640626414

87. Dunphy JT, Linder ME (1998) Signalling functions of protein palmitoylation. Biochim Biophys Acta Mol Cell Biol Lipids 1436:245-261

88. Melkonian KA, Ostermeyer AG, Chen JZ et al (1999) Role of lipid modifications in targeting proteins to detergentresistant membrane rafts - Many raft proteins are acylated, while few are prenylated. J Biol Chem 274:3910-3917 
89. Mizumoto N, Kumamoto T, Robson SC et al (2002) CD39 is the dominant Langerhans cell associated ecto-NTPDase: Modulatory roles in inflammation and immune responsiveness. Nat Med 8:358-365

90. Eltzschig HK, Ibla JC, Furuta GT et al (2003) Coordinated adenine nucleotide phosphohydrolysis and nucleoside signaling in posthypoxic endothelium: Role of ectonucleotidases and adenosine $\mathrm{A}_{2 \mathrm{~B}}$ receptors. J Exp Med 198: 783-796

91. Dzhandzhugazyan KN, Kirkin AF, Straten PT et al (1998) Ecto-ATP diphosphohydrolase/CD39 is overexpressed in differentiated human melanomas. FEBS Lett 430:227-230

92. Kapojos JJ, VandenBerg A, Borghuis T et al (2004) Enhanced ecto-apyrase activity of stimulated endothelial or mesangial cells is downregulated by glucocorticolds in vitro. Eur J Pharmacol 501:191-198

93. Cheung PK, Visser J, Bakker WW (1994) Upregulation of antithrombotic ectonucleotidases by aspirin in human endothelial cells in-vitro. J Pharm Pharmacol 46:1032-1034

94. Faas MM, Bakker WW, Klok PA et al (1997) Modulation of glomerular ecto-ADPase expression by oestradiol - A histochemical study. Thromb Haemost 77:767-771

95. Gao L, Dong LQ, Whitlock JP (1998) A novel response to dioxin - Induction of ecto-ATPase gene expression. J Biol Chem 273:15358-15365

96. Gao L, Whitlock JP (2001) Accessibility and activity of the promoter for a dioxin-inducible ecto-ATPase gene. Arch Biochem Biophys 392:270-278

97. Wood E, Broekman MJ, Kirley TL et al (2002) Cell-type specificity of ectonucleotidase expression and upregulation by 2,3,7,8-tetrachlorodibenzo- $p$-dioxin. Arch Biochem Biophys 407:49-62

98. Lu QX, Porter LD, Cui XM et al (2001) Ecto-ATPase mRNA is regulated by FSH in Sertoli cells. J Androl 22:289-301

99. Dranoff JA, Kruglov EA, Toure J et al (2004) Ectonucleotidase NTPDase2 is selectively down-regulated in biliary cirrhosis. J Investig Med 52:475-482

100. Wiendl HS, Schneider C, Ogilvie A (1998) Nucleotide metabolizing ectoenzymes are upregulated in A431 cells periodically treated with cytostatic ATP leading to partial resistance without preventing apoptosis. Biochim Biophys Acta Mol Cell Res 1404:282-298

101. Gendron FP, Benrezzak O, Krugh BW et al (2002) Purine signaling and potential new therapeutic approach: Possible outcome of NTPDase inhibition. Current Drug Targets 3:229-245

102. Ravi RG, Kim HS, Servos J et al (2002) Adenine nucleotide analogues locked in a northern methanocarba conformation: Enhanced stability and potency as $\mathrm{P}_{2} \mathrm{Y}_{1}$ receptor agonists. J Med Chem 45:2090-2100

103. Kennedy C, Westfall TD, Sneddon P (1996) Modulation of purinergic neurotransmission by ecto-ATPase. Semin Neurosci 8:195-199

104. Westfall TD, Kennedy C, Sneddon P (1997) The ectoATPase inhibitor ARL 67156 enhances parasympathetic neurotransmission in the guinea-pig urinary bladder. Eur J Pharmacol 329:169-173

105. Drakulich DA, Spellmon C, Hexum TD (2004) Effect of the ecto-ATPase inhibitor, ARL 67156, on the bovine chromaffin cell response to ATP. Eur J Pharmacol 485:137-140

106. Gendron FP, Halbfinger E, Fischer B et al (2000) Novel inhibitors of nucleoside triphosphate diphosphohydrolases: Chemical synthesis and biochemical and pharmacological characterizations. J Med Chem 43:2239-2247
107. Beigi RD, Kertesy SB, Aquilina G et al (2003) Oxidized ATP (OATP) attenuates proinflammatory signaling via $\mathrm{P} 2$ receptor-independent mechanisms. Brit J Pharmacol 140:507-519

108. Escalada A, Navarro P, Ros E et al (2004) Gadolinium inhibition of ecto-nucleoside triphosphate diphosphohydrolase activity in Torpedo electric organ. Neurochem Res 29:1711-1714

109. Heine P, Braun N, Zimmermann H (1999) Functional characterization of rat ecto-ATPase and ecto-ATP diphosphohydrolase after heterologous expression in $\mathrm{CHO}$ cells. Eur J Biochem 262:102-107

110. Hoffmann C, Heine P, Pradel G et al (2000) Inhibition of ecto-apyrase and ecto-ATPase by pyridoxal phosphaterelated compounds. Drug Dev Res 51:153-158

111. Iqbal J, Vollmayer P, Braun N et al (2005) A capillary electrophoresis method for the characterization of ectonucleoside triphosphate diphosphohydrolases (NTPDases) and the screening of inhibitors by in-capillary enzymatic microreactions. Purinergic Signalling 1:349-358

112. Enjyoji K, Sévigny J, Lin Y et al (1999) Targeted disruption of $c d 39 /$ ATP diphosphohydrolase results in disordered hemostasis and thromboregulation. Nat. Med 5:1010-1017

113. Goepfert C, Imai M, Brouard S et al (2000) CD39 modulates endothelial cell activation and apoptosis. Mol Med 6:591-603

114. Vigne P, Breittmayer JP, Frelin C (1998) Analysis of the influence of nucleotidases on the apparent activity of exogenous ATP and ADP at $\mathrm{P}_{2} \mathrm{Y}_{1}$ receptors. Br J Pharmacol 125:675-680

115. Alvarado-Castillo C, Harden TK, Boyer JL (2005) Regulation of $\mathrm{P}_{2} \mathrm{Y}_{1}$ receptor-mediated signaling by the ectonucleoside triphosphate diphosphohydrolase isozymes NTPDase1 and NTPDase2. Mol Pharmacol 67:114-122

116. He ML, Gonzales-Iglesias AE, Tomic M et al (2005) Release and extracellular metabolism of ATP by ectonucleotidase eNTPDase 1-3 in hypothalamic and pituitary cells. Purinergic Signalling 1:135-144

117. Jhandier MN, Kruglov EA, Lavoie ÉG et al (2005) Portal fibroblasts regulate the proliferation of bile duct epithelia via expression of NTPDase2. J Biol Chem 280:22986-22992

118. Anderson RGW (1998) The caveolae membrane system. Annu Rev Biochem 67:199-225

119. Shaul PW, Anderson RGW (1998) Role of plasmalemmal caveolae in signal transduction. Am J Physiol - Lung Cell Mol Physiol 19:L843-L851

120. Velazquez B, Garrad RC, Weisman GA et al (2000) Differential agonist-induced desensitization of $\mathrm{P}_{2} \mathrm{Y}_{2}$ nucleotide receptors by ATP and UTP. Mol Cell Biochem 206:75-89

121. Weisman GA, Griffin K, Santiago-Perez LI et al (2001) $\mathrm{P}_{2} \mathrm{Y}_{2}$ receptors regulate multiple signal transduction pathways in monocytic cells. Drug Dev Res 53:186-192

122. Zhong XT, Malhotra R, Guidotti G (2000) Regulation of yeast ectoapyrase Ynd1p activity by activator subunit Vma13p of vacuolar $\mathrm{H}^{+}$-ATPase. J Biol Chem 275:3559235599

122a. Wu Y, Sun X, Kaczmarek E et al (2006) Ran BPM associates with $\mathrm{CD} 39$ and modulates ecto-nucleotidase activity. Biochem J, Epub ahead of print.

123. Wang DK, Li ZB, Messing EM et al (2002) Activation of Ras/Erk pathway by a novel MET-interacting protein RanBPM. J Biol Chem 277:36216-36222

124. Wu Y, Sun X, Enjyoji K et al (2004) NTPDase1 interacts with RanBPM to directly modulate Ras activation and 
cellular proliferation in liver regeneration following partial hepatectomy. Hepatology 135:222

125. Hall RA, Ostedgaard LS, Premont RT et al (1998) A Cterminal motif found in the $\beta 2$-adrenergic receptor, $\mathrm{P}_{2} \mathrm{Y}_{1}$ receptor and cystic fibrosis transmembrane conductance regulator determines binding to the $\mathrm{Na}^{+} / \mathrm{H}^{+}$exchanger regulatory factor family of PDZ proteins. Proc Natl Acad Sci U S A 95:8496-8501

126. Saras J, Heldin CH (1996) PDZ domains bind carboxyterminal sequences of target proteins. Trends Biochem Sci 21:455-458

127. Fan JS, Zhang M (2002) Signalling complex organization by PDZ domain proteins. NeuroSignals 11:315-321

128. Hung AY, Sheng M (2002) PDZ domains: Structural modules for protein complex assembly. J Biol Chem 277:5699-5702

129. North RA (1996) P2X purinoceptor plethora. Semin Neurosci 8:187-194

130. Bodas E, Aleu J, Pujol G et al (2000) ATP crossing the cell plasma membrane generates an ionic current in Xenopus oocytes. J Biol Chem 275:20268-20273

131. Ross R (1995) Cell biology of atherosclerosis. Annu Rev Physiol 57:791-804

132. Marcus AJ, Safier LB, Hajjar KA et al (1991) Inhibition of platelet function by an aspirin-insensitive endothelial cell ADPase. Thromboregulation by endothelial cells. J Clin Invest 88:1690-1696

133. Marcus AJ, Broekman MJ, Drosopoulos JHF et al (2003) Metabolic control of excessive extracellular nucleotide accumulation by CD39/ecto-nucleotidase-1: Implications for ischemic vascular diseases. $\mathrm{J}$ Pharmacol Exp Ther 305:9-16

134. Goepfert C, Sundberg C, Sévigny J et al (2001) Disordered cellular migration and angiogenesis in cd39-null mice. Circulation 104:3109-3115

135. Wang LW, Andersson M, Karlsson L et al (2003) Increased mitogenic and decreased contractile $\mathrm{P} 2$ receptors in smooth muscle cells by shear stress in human vessels with intact endothelium. Arterioscler Thromb Vasc Biol 23:1370-1376

136. Wihlborg AK, Wang LW, Braun OO et al (2004) ADP receptor $\mathrm{P}_{2} \mathrm{Y}_{12}$ is expressed in vascular smooth muscle cells and stimulates contraction in human blood vessels. Arterioscler Thromb Vasc Biol 24:1810-1815

137. Mulero JJ, Yeung G, Nelken ST et al (1999) CD39-L4 is a secreted human apyrase, specific for the hydrolysis of nucleoside diphosphates. J Biol Chem 29:20064-20067

138. Robson SC, Sévigny J, Imai M et al (2000) Thromboregulatory potential of endothelial CD39/nucleoside triphosphate diphosphohydrolase: Modulation of purinergic signalling in platelets. Emerg Ther Targets 4:155-171

139. Robson SC (2001) Thromboregulation by endothelial cells: Significance for occlusive vascular diseases. Arterioscler Thromb Vasc Biol 21:1251

140. Luscinskas FW, Lawler J (1994) Integrins as dynamic regulators of vascular function. FASEB J 8:929-938

141. Schwartz MA, Schaller MD, Ginsberg MH (1995) Integrins-emerging paradigms of signal transduction. Annu Rev Cell Dev Biol 11:549-599

142. Shattil SJ (1999) Signaling through platelet integrin $\alpha_{\mathrm{IIb}}, \beta_{3}$ : Inside-out, outside-in, and sideways. Thromb Haemost 82:318-325

143. Kaczmarek E, Erb L, Koziak K et al (2005) Modulation of endothelial cell migration by extracellular nucleotides Involvement of focal adhesion kinase and phosphatidylinositol 3-kinase-mediated pathways. Thromb Haemost 93: 735-742
144. Giancotti F, Ruoslahti E (1999) Integrin signalling. Science 285:102-104

145. Pinsky DJ, Broekman MJ, Peschon JJ et al (2002) Elucidation of the thromboregulatory role of CD39/ectoapyrase in the ischemic brain. J Clin Invest 109:10311040

146. Dwyer KM, Robson SC, Nandurkar HH et al (2004) Thromboregulatory manifestations in human CD39 transgenic mice and the implications for thrombotic disease and transplantation. J Clin Invest 113:1440-1446

147. Imai M, Takigami K, Guckelberger O et al (2000) Recombinant adenoviral mediated CD39 gene transfer prolongs cardiac xenograft survival. Transplantation 70:864-870

148. Koyamada N, Miyatake T, Candinas D et al (1996) Apyrase administration prolongs discordant xenograft survival. Transplantation 62:1739-1743

149. Candinas D, Koyamada N, Miyatake T et al (1996) Loss of rat glomerular ATP diphosphohydrolase activity during reperfusion injury is associated with oxidative stress reactions. Thromb Haemost 76:807-812

150. Guckelberger O, Sun XF, Sévigny J et al (2004) Beneficial effects of CD39/ecto-nucleoside triphosphate diphosphohydrolase-I in murine intestinal ischemia-reperfusion injury. Thromb Haemost 91:576-586

151. Diazflores L, Gutierrez R, Varela H (1994) Angiogenesis An update. Histol Histopathol 9:807-843

152. Hirschi KK, Damore PA (1996) Pericytes in the microvasculature. Cardiovasc Res 32:687-698

153. Beck L, Damore PA (1997) Vascular development-cellular and molecular regulation. FASEB J 11:365-373

154. Sampram ES, Ouriel K (2004) In vitro verification of antithrombotic effect of recombinant soluble nucleotide triphosphate diphosphohydrolase 1. J Vasc Interv Radiol 15:379-384

155. Hatakeyama H, Hao H, Imamura $\mathrm{T}$ et al (2005) Relation of CD39 to plaque instability and thrombus formation in directional atherectomy specimens from patients with stable and unstable angina pectoris. Am J Cardiol 95:632635

156. Kansas GS, Wood GS, Tedder TF (1991) Expression, distribution, and biochemistry of human CD39: Role in activation-associatied homotypic adhesion of lymphocytes. J Immunol 146:2235-2244

157. Stockl J, Majdic O, Fischer G et al (2001) Monomorphic molecules function as additional recognition structures on haptenated target cells for HLA-A1-restricted, haptenspecific CTL. J Immunol 167:2724-2733

158. Berchtold S, Ogilvie ALJ, Bogdan C et al (1999) Human monocyte derived dendritic cells express functional P2X and $\mathrm{P} 2 \mathrm{Y}$ receptors as well as ecto-nucleotidases. FEBS Lett 458:424-428

159. Salmi M, Jalkanen S (2005) Cell-surface enzymes in control of leukocyte trafficking. Nat Rev Immunol 5:760-771

160. Holm T, Nielsson J, Claesson M (2004) $\mathrm{CD}^{+}$and $\mathrm{CD} 25^{+}$ regulatory T cells: I. Phenotype and physiology. APMIS 112:629-641

161. Feranchak AP, Fitz JG (2002) Adenosine triphosphate release and purinergic regulation of cholangiocyte transport. Semin Liver Dis 22:251-262

162. Boudreault F, Grygorczyk R (2004) Cell swelling-induced ATP release is tightly dependent on intracellular calcium elevations. J Physiol London 561:499-513

163. Leipziger J (2003) Control of epithelial transport via luminal P2 receptors. Am J Physiol Renal Physiol 284:F419F432 
164. Dubyak GR (2003) Knock-out mice reveal tissue-specific roles of P2Y receptor subtypes in different epithelia. Mol Pharmacol 63:773-776

165. Keppens S, VandeKerckhove J, De Wulf H (1989) Characterization of purinoceptors present on human liver plasma membranes. FEBS Lett 248:137-140

166. Keppens S (1993) The complex interaction of ATP and UTP with isolated hepatocytes. How many receptors? Gen Pharmacol 24:283-289

167. Che MX, Nishida T, Gatmaitan Z et al (1992) A nucleoside transporter is functionally linked to ectonucleotidases in rat liver canalicular membrane. J Biol Chem 267:9684-9688

168. Chari RS, Schutz SM, Haebig JE et al (1996) Adenosine nucleotides in bile. Am J Physiol Gastroin Liver Physiol 33:G246-G252

169. Keppler D, Arias IM (1997) Introduction - Transport across the hepatocyte canalicular membrane. FASEB J 11:15-18

170. Schlosser SF, Burgstahler AD, Nathanson JA (1996) Isolated rat hepatocytes can signal to other hepatocytes and bile duct cells by release of nucleotides. Proc Natl Acad Sci USA 93:9948-9953

171. Thevananther S, Sun H, Li D et al (2004) Extracellular ATP activates c-Jun N-terminal kinase signalling and cell cycle progression in hepatocytes. Hepatology 39:393-402

172. Scott LJ, Delautier D, Meerson NR et al (1997) Biochemical and molecular identification of distinct forms of alkaline phosphodiesterase I expressed on the apical and basolateral plasma membrane surfaces of rat hepatocytes. Hepatology 25:995-1002

173. Goding JW, Terkeltaub R, Maurice M et al (1998) Ectophosphodiesterase/pyrophosphatase of lymphocytes and non-lymphoid cells: Structure and function of the PC-1 family. Immunol Rev 161:11-26

174. Sévigny J, Robson SC, Waelkens E et al (2000) Identification and characterization of a novel hepatic canalicular ATP diphosphohydrolase. J Biol Chem 275:5640-5647

175. Dranoff JA, Kruglov EA, Robson SC et al (2002) The ectonucleoside triphosphate diphosphohydrolase NTPDase2/ CD39L1 is expressed in a novel functional compartment within the liver. Hepatology 36:1135-1144

176. Dranoff JA, Ogawa M, Kruglov EA et al (2004) Expression of $\mathrm{P} 2 \mathrm{Y}$ nucleotide receptors and ectonucleotidases in quiescent and activated rat hepatic stellate cells. Am J Physiol Gastrointest Liver Physiol 287:G417-G424

177. Smith TM, Kirley TL (1998) Cloning, sequencing, and expression of a human brain ecto-apyrase related to both the ecto-ATPases and CD39 ecto-apyrases. Biochim Biophys Acta 1386:65-78

178. Novikoff AB, Essner E (1960) The liver cell: Some new approaches to its study. Am J Med 29:102-131

179. Lin S-H, Guidotti G (1989) Cloning and expression of a cDNA coding for a rat liver plasma membrane ectoATPase. The primary structure of the ecto-ATPase is similar to that of the human biliary glycoprotein I. J Biol Chem 264:14408-1414

180. Lin SH, Culic O, Flanagan D et al (1991) Immunochemical characterization of two isoforms of rat liver ecto-ATPase that show an immunological and structural identity with a glycoprotein cell-adhesion molecule with $\mathrm{M}_{\mathrm{r}}-105000$. Biochem J 278:155-161

181. Knowles AF (1995) The rat liver ecto-ATPase/c-CAM cDNA detects induction of carcinoembryonic antigen but not the mercurial-insensitive ecto-ATPase in human hepatoma li-7a cells treated by epidermal growth factor and cholera toxin. Biochem Biophys Res Commun 207:529_ 535

182. Leclerc MC, Grondin G, Gendron FP et al (2000) Identification, characterization, and immunolocalization of a nucleoside triphosphate diphosphohydrolase in pig liver. Arch Biochem Biophys 377:372-378

183. Nagy AK, Knowles AF, Nagami GT (1998) Molecular cloning of the chicken oviduct ecto-ATP-diphosphohydrolase. J Biol Chem 273:16043-16049

184. Knowles AF, Nagy AK, Strobel RS et al (2002) Purification, characterization, cloning, and expression of the chicken liver ecto-ATP-diphosphohydrolase. Eur J Biochem 269:2373-2382

185. Che MX, Gatmaitan Z, Arias IM (1997) Ectonucleotidases, purine nucleoside transporter, and function of the bile canalicular plasma membrane of the hepatocyte. FASEB J 11:101-108

186. Lajtha LG, Vane JR (1958) Dependence of bone marrow cells on the liver for purine salvage. Nature 182:191-192

187. Novak I, Amstrup J, Henriksen KL et al (2003) ATP release and effects in pancreas. Drug Dev Res 59:128-135

188. Sorensen CE, Amstrup J, Rasmussen HN et al (2003) Rat pancreas secretes particulate ecto-nucleotidase CD39. J Physiol London 551:881-892

189. Lambert M, Christophe J (1978) Characterization of (Mg,Ca)-ATPase activity in rat pancreatic plasma membranes. Eur J Biochem 91:485-492

190. Martin SS, Senior AE (1980) Membrane adenosine triphosphatase activities in rat pancreas. Biochim Biophys Acta 602:401-418

191. LeBel D, Poirier GG, Phaneuf S et al (1980) Characterization and purification of a calcium-sensitive ATP diphosphohydrolase from pig pancreas. J Biol Chem 255:12271233

192. Laliberté JF, St-Jean P, Beaudoin AR (1982) Kinetic effects of $\mathrm{Ca}^{2+}$ and $\mathrm{Mg}^{2+}$ on ATP hydrolysis by the purified ATP diphosphohydrolase. J Biol Chem 257:3869-3874

193. Beaudoin AR, Laliberté JF, LeBel D et al (1980) Localization and physiological role of the ATP-diphosphohydrolase in the pancreatic acinar cell. In: Ribet A, Pradayrol L, Susini C (eds) Biology of normal and cancerous exocrine pancreatic cells. Elsevier, Elsevier, pp 273-218

194. Kittel A, Pelletier J, Bigonnesse F et al (2004) Localizaspace]tion of nucleoside triphosphate diphosphohydrolase1 (NTPDase1) and NTPDase2 in pancreas and salivary gland. J Histochem Cytochem 52:861-871

195. Kordas KS, Sperlagh B, Tihanyi T et al (2004) ATP and ATPase secretion by exocrine pancreas in rat, guinea pig, and human. Pancreas 29:53-60

196. Sévigny J, Grondin G, Gendron FP et al (1998) Demonstration and immunolocalization of ATP diphosphohydrolase in the pig digestive system. Am J Physiol Gastrointest Liver Physiol 38:G473-G482

197. Schnermann J, Levine DZ (2003) Paracrine factors in tubuloglomerular feedback: Adenosine, ATP, and nitric oxide. Annu Rev Physiol 65:501-529

198. Komlosi P, Fintha A, Bell PD (2005) Renal cell-to-cell communication via extracellular ATP. Physiology 20:8690

199. Kishore BK, Isaac J, Fausther M et al (2005) Expression of NTPDase1 and NTPDase2 in murine kidney: Relevance to regulation of $\mathrm{P} 2$ receptor signaling. Am J Physiol Renal Physiol 288:F1032-F1043

200. Lemmens R, Kupers L, Sévigny J et al (2000) Purification, characterization, and localization of an ATP diphosphohy- 
drolase in porcine kidney. Am J Physiol Renal Physiol 278:F978-F988

201. Vekaria RM, Shirley DG, Sévigny J et al (2006) Immunolocalisation of ectonucleotidases along the rat nephron. Am J Physiol Renal Physiol 290:550-560

202. Kawamura M, Gachet C, Inoue $K$ et al (2004) Direct excitation of inhibitory interneurons by extracellular ATP mediated by $\mathrm{P}_{2} \mathrm{Y}_{1}$ receptors in the hippocampal slice. J Neurosci 24:10835-10845

203. Araque A, Perea G (2004) Glial modulation of synaptic transmission in culture. Glia 47:241-248

204. Weisman GA, Wang M, Kong Q et al (2005) Molecular determinants of $\mathrm{P}_{2} \mathrm{Y}_{2}$ nucleotide receptor function: Implications for proliferative and inflammatory pathways in astrocytes. Mol Neurobiol 31:1-15

205. Davalos D, Grutzendler J, Yang G et al (2005) ATP mediates rapid microglial response to local brain injury in vivo. Nat Neurosci 8:752-758

206. Burnstock G (1995) Noradrenaline and ATP: Cotransmitters and neuromodulators. J Physiol Pharmacol 365-384

207. Spyer KM, Dale N, Gourine AV (2004) ATP is a key mediator of central and peripheral chemosensory transduction. Exp Physiol 89:53-59

208. Stevens B, Fields RD (2000) Response of Schwann cells to action potentials in development. Science 287:2267-2271

209. Dunwiddie TV, Diao LH, Proctor WR (1997) Adenine nucleotides undergo rapid, quantitative conversion to adenosine in the extracellular space in rat hippocampus. J Neurosci 17:7673-7682

210. Cunha RA, Sebastiao AM, Ribeiro JA (1998) Inhibition by ATP of hippocampal synaptic transmission requires localized extracellular catabolism by ecto-nucleotidases into adenosine and channeling to adenosine A1 receptors. J Neurosci 18:1987-1995

211. Kato F, Kawamura M, Shigetomi E et al (2004) ATP- and adenosine-mediated signaling in the central nervous system: Synaptic purinoceptors: the stage for ATP to play its "dualrole”. J Pharmacol Sci 94:107-111

212. Wang TF, Guidotti G (1998) Widespread expression of ecto-apyrase (CD39) in the central nervous system. Brain Res 790:318-322

213. Kukulski F, Komoszynski M (2003) Purification and characterization of NTPDase1 (Ecto-apyrase) and NTPDase2 (Ecto-ATPase) from porcine brain cortex synaptosomes. Eur J Biochem 270:3447-3454

214. Kukulski F, Sévigny J, Komoszynski M (2004) Comparative hydrolysis of extracellular adenine nucleotides and adenosine in synaptic membranes from porcine brain cortex, hippocampus, cerebellum and medulla oblongata. Brain Res 1030:49-56

215. Nagy AK (1997) Ecto-ATPases of the nervous system. In: Plesner L, Kirley TL, Knowles AF (eds) Ecto-ATPases: Recent progress in structure and function. Plenum, New York, pp 1-13

216. James S, Richardson PJ (1993) Production of adenosine from extracellular ATP at the striatal cholinergic synapse. J Neurochem 60:219-227

217. Cunha RA (2001) Regulation of the ecto-nucleotidase pathway in rat hippocampal nerve terminals. Neurochem Res 26:979-991

218. Belcher SM, Zsarnovzky A, Crawford PA et al (2006) Immunolocalization of ecto-nucleoside triphosphate diphosphohydrolase 3 in rat brain: Implications for modulation of multiple homeostatic systems including feeding and sleep wake behaviors. Neuroscience 137: 1331-1346
219. Wink MR, Braganhol E, Tamajusuku ASK et al (2003) Extracellular adenine nucleotides metabolism in astrocyte cultures from different brain regions. Neurochem Int 43:621-628

220. Lai KM, Wong PCL (1991) Metabolism of extracellular adenine nucleotides by cultured rat brain astrocytes. J Neurochem 57:1510-1515

221. Braun N, Sévigny J, Mishra S et al (2003) Expression of the ecto-ATPase NTPDase2 in the germinal zones of the developing and adult rat brain. Eur J Neurosci 17:13551364

222. Shukla V, Zimmermann H, Wang L et al (2005) Functional expression of the ecto-ATPase NTPDase 2 and of nucleotide receptors by neuronal progenitor cells in the adult murine hippocampus. J Neurosci Res 80:600-610

223. Wilhelm A, Volknandt W, Langer D et al (2004) Localization of SNARE proteins and secretory organelle proteins in astrocytes in vitro and in situ. Neurosci Res 48: 249-257

224. Braun N, Zimmermann H (2001) Microglial ectonucleotidases: Identification and functional roles. Drug Dev Res 53:208-217

225. Braun N, Sévigny J, Robson SC et al (2000) Assignment of ecto-nucleoside triphosphate diphosphohydrolase-1/cd39 expression to microglia and vasculature of the brain. Eur $\mathbf{J}$ Neurosci 12:4357-4366

226. Steindler DA, Laywell ED (2003) Astrocytes as stem cells: Nomenclature, phenotype and translation. Glia 43:62-69

227. Mishra SK, Braun N, Shukla V et al (2006) Extracellular nucleotide signaling in adult neural stem cells: Synergism with growth factor-mediated cellular proliferation. Development 133: 675-684

228. Vollmayer P, Koch M, Braun N et al (2001) Multiple ectonucleotidases in PC12 cells: Identification and cellular distribution after heterologous expression. J Neurochem 78:1019-1028

229. Machida T, Heerdt PM, Reid AC et al (2005) Ectonucleoside triphosphate diphosphohydrolase1/CD39, localized in neurons of human and porcine heart, modulates ATPinduced norepinephrine exocytosis. J Pharmacol Exp Ther 313:570-577

230. Mihaylova-Todorova ST, Todorov LD, Westfall DP (2002) Enzyme kinetics and pharmacological characterization of nucleotidases released from the guinea pig isolated vas deferens during nerve stimulation: Evidence for a soluble ecto-nucleoside triphosphate diphosphohydrolase-like ATPase and a soluble ecto-5'-nucleotidase-like AMPase. J Pharmacol Exp Ther 302:992-1001

231. Braun N, Sévigny J, Robson SC et al (2004) Association of the ecto-ATPase NTPDase2 with glial cells of the peripheral nervous system. Glia 45:124-132

232. Vlajkovic SM, Thorne PR, Munoz DJB et al (1996) Ectonucleotidase activity in the perilymphatic compartment of the guinea pig cochlea. Hear Res 99:31-37

233. Vlajkovic SM, Thorne PR, Housley GD et al (1998) The pharmacology and kinetics of ecto-nucleotidases in the perilymphatic compartment of the guinea-pig cochlea. Hear Res 117:71-80

234. Vlajkovic SM, Thorne PR, Sévigny J et al (2002) Distribution of ectonucleoside triphosphate diphosphohydrolases 1 and 2 in rat cochlea. Hear Res 170:127-138

235. Vlajkovic SM, Thorne PR, Sévigny J et al (2002) NTPDase1 and NTPDase2 immunolocalization in mouse cochlea: Implications for regulation of P2 receptor signaling. J Histochem Cytochem 50:1435-1441 
236. Vlajkovic SM, Housley GD, Munoz DJB et al (2004) Noise exposure induces up-regulation of ecto-nucleoside triphosphate diphosphohydrolases 1 and 2 in rat cochlea. Neuroscience 126:763-773

237. Bo XN, Alavi A, Xiang ZH et al (1999) Localization of ATP-gated $\mathrm{P} 2 \mathrm{X}_{2}$ and $\mathrm{P} 2 \mathrm{X}_{3}$ receptor immunoreactive nerves in rat taste buds. Neuroreport 10:1107-1111

238. Baryshnikov SG, Rogachevskaja OA, Kolesnikov SS (2003) Calcium signaling mediated by $\mathrm{P} 2 \mathrm{Y}$ receptors in mouse taste cells. J Neurophysiol 90:3283-3294

239. Kataoka S, Toyono T, Seta Y et al (2004) Expression of $\mathrm{P}_{2} \mathrm{Y}_{1}$ receptors in rat taste buds. Histochem Cell Biol 121:419-426

240. Finger TE, Danilova V, Barrows J et al (2005) ATP signaling is crucial for communication from taste buds to gustatory nerves. Science 310:1495-1499

241. Bartel DL, Sullivan SL, Lavoie ÉG et al (2006) Nucleoside triphosphate diphosphohydrolase-2 (NTPDase2) is the ecto-ATPase of taste buds. J Comp Neurol 499 (in press)

242. Braun N, Zhu Y, Krieglstein J et al (1998) Upregulation of the enzyme chain hydrolyzing extracellular ATP following transient forebrain ischemia in the rat. J Neurosci 18:48914900

243. Schetinger MRC, Bonan CD, Schierholt R et al (1998) Nucleotide hydrolysis in rats submitted to global cerebral ischemia: A possible link between preconditioning and adenosine production. J Stroke Cerebrovasc Dis 7:281-286

244. Ferrari D, Chiozzi P, Falzoni S et al (1997) ATP-mediated cytotoxicity in microglial cells. Neuropharmacology 36:1295-L301

245. Bianco F, Fumagalli M, Pravettoni E et al (2005) Pathophysiological roles of extracellular nucleotides in glial cells: Differential expression of purinergic receptors in resting and activated microglia. Brain Res Rev 48:144-156

246. Bonan CD, Roesler R, Pereira GS et al (2000) Learningspecific decrease in synaptosomal ATP diphosphohydrolase activity from hippocampus and entorhinal cortex of adult rats. Brain Res 854:253-256

247. Nagy AK, Houser CR, Delgado-Escueta AV (1990) Synaptosomal ATPase activities in temporal cortex and hippocampal formation of humans with focal epilepsy. Brain Res 529:192-201

248. Nagy AK, Walton NY, Treiman DM (1997) Reduced cortical ecto-ATPase activity in rat brains during prolonged status epilepticus induced by sequential administration of lithium and pilocarpine. Mol Chem Neuropathol $31: 135-147$
249. Bonan CD, Walz R, Pereira GS et al (2000) Changes in synaptosomal ectonucleotidase activities in two rat models of temporal lobe epilepsy. Epilepsy Res 39:229-238

250. Bonan CD, Amaral OB, Rockenbach IC et al (2000) Altered ATP hydrolysis induced by pentylenetetrazol kindling in rat brain synaptosomes. Neurochem Res 25:775-779

251. Da Silva RS, Bruno AN, Battastini AMO et al (2003) Acute caffeine treatment increases extracellular nucleotide hydrolysis from rat striatal and hippocampal synaptosomes. Neurochem Res 28:1249-1254

252. Mateo J, Harden TK, Boyer JL (1999) Functional expression of a cDNA encoding a human ecto-ATPase. Brit J Pharmacol 128:396-402

253. Wang TF, Guidotti G (1998) Golgi localization and functional expression of human uridine diphosphatase. J Biol Chem 273:11392-1139

254. Biederbick A, Kosan C, Kunz J et al (2000) First apyrase splice variants have different enzymatic properties. J Biol Chem 275:19018-19024

255. Trombetta ES, Helenius A (1999) Glycoprotein reglycosylation and nucleotide sugar utilization in the secretory pathway: identification of a nucleoside diphosphatase in the endoplasmic reticulum. EMBO J 18:3282-3292

256. Páez JG, Recio JA, Rouzaut A et al (2001) Identity between the PCPH proto-oncogene and the CD39L4 (ENTPD5) ectonucleoside triphosphate diphosphohydrolase gene. Int J Oncol 19:1249-1254

257. Yeung G, Mulero JJ, McGowan DW et al (2000) CD39L2, a gene encoding a human nucleoside diphosphatase, predominantly expresssed in the heart. Biochemistry USA 39:12916-12923

258. Hicks-Berger CA, Chadwick BP, Frischauf AM et al (2000) Expression and characterization of soluble and membranebound human nucleoside triphosphate diphosphohydrolase 6 (CD39L2). J Biol Chem 275:34041-34045

259. Braun N, Fengler S, Ebeling $C$ et al (2000) Sequencing, functional expression and characterization of NTPDase6, a nucleoside diphosphatase and novel member of the ectonucleoside triphosphate diphosphohydrolase family. Biochem J 351:639-647

260. Shi JD, Kukar T, Wang CY et al (2001) Molecular cloning and characterization of a novel mammalian endo-apyrase (LALP1). J Biol Chem 276:17474-17478

261. Maki T, Gottschalk R, Monaco AP (2002) Prevention of autoimmune diabetes by FTY720 in nonobese diabetic mice. Transplantation 74:1684-1686 